\title{
Możliwości zastosowania zdalnego systemu monitoringu wgłębnego i powierzchniowego osuwisk w kopalni odkrywkowej węgla brunatnego na podstawie badań wykonanych w KWB Belchatów w ramach projektu UE RFCS Slopes
}

\author{
Zbigniew Bednarczyk ${ }^{1}$
}

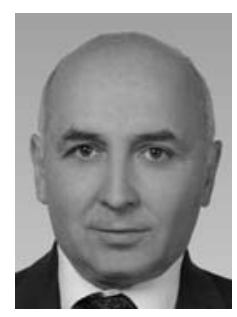

Possibilities of implementation of remote in situ and surface displacement landslide monitoring in lignite opencast mine based on the research conducted within the EU RFCS Slopes project. Prz. Geol., 69: 785-799; doi: $10.7306 / 2021.41$

A b s t r a c t. Landslides in Polish opencast lignite mines are a serious problem for the efficiency of exploitation. They can also pose a threat to adjacent areas and the environment, and in some cases even jeopardize the continuity of lignite supplies to power plants. Such phenomena are associated with a number of factors, the most important of which are the geological engineering structure, groundwater conditions, unfavourable strength parameters of clayey soils and their usually relatively steep slopes. Counteracting such a phenomena, caused by mining activity, is usually difficult because of large size of landslides and the depth of exploitation reaching in some cases over $300 \mathrm{~m}$. The paper presents the first application of on-line monitoring in a Polish opencast lignite mine. Performed in the Betchatów Mine, in situ monitoring was complemented by satellite radar interferometry (PSI), LiDAR airborne laser scanning, and terrestrial laser scanning. Research within the RFCS EU SLOPES project "Smarter Lignite Open Pit Engineering Solutions" was performed by an international consortium from six European countries. In Poland, the research was located mainly on the western slope of the Betchatów Field. In this area, in the Polish open pit lignite mine, on-line inclinometer, and a pore pressure monitoring system were the first located at the levels of $+42:-58 \mathrm{~m}$ a.s.l. Geological engineering investigations included $100 \mathrm{~m}$ depth core drilling, index laboratory tests, IL oedometer tests, CIU, CID triaxial tests, and numerical modelling. The total amount of in situ displacement, during the period December 2016-July 2019, reached $290 \mathrm{~mm}$. The largest displacements up to $250 \mathrm{~mm}$ were recorded: to a depth of $45 \mathrm{~m}$ in the direction of slope inclination, and smaller ones up to $50 \mathrm{~mm}$ to a depth of $72.5 \mathrm{~m}$. The displacements were accompanied by a decre ase in pore pressure values by more than $200 \mathrm{kPa}$. In other parts of the mine and adjacent areas, the satellite radar interferometry detected displacements up to $60 \mathrm{~mm} /$ year on the outer slopes of the Szczerców dump. It also allowed identification of the landslide hazard in other areas. Data obtained from in-situ monitoring and laboratory tests on the western slope of the Betchatów Field were included in numerical modelling using the shear strength reduction method and the limit equilibrium method. This should allow helping for better recognition and warning of the existing hazards in the investigated area.

Keywords: geological engineering monitoring, slope stability, opencast lignite mine

W kopalniach odkrywkowych węgla brunatnego osuwiska są często związane $\mathrm{z}$ działalnością górniczą. Ze względu na duże rozmiary i głębokość wyrobisk odkrywkowych stwarzają one szereg zagrożeń. Jednym z nich jest konieczność składowania bardzo dużych mas nadkładu na zwałowiskach zewnętrznych i wewnętrznych. Sprawia to, że ryzyko osuwiskowe wzrasta. Osuwiska mogą powodować zagrożenie dla efektywności eksploatacji oraz negatywnie oddziaływać na środowisko (Bednarczyk, Nowak, 2010; Bednarczyk, 2017a). Na wielkość zagrożenia osuwiskowego ma wpływ budowa geologiczna, parametry wytrzymałościowe gruntów, zagospodarowanie terenu, opady atmosferyczne, zmiany poziomu wód gruntowych wywołane odwadnianiem, częściowa saturacja gruntów, stosowanie materiałów wybuchowych, sejsmiczność naturalna, procesy krasowe, infiltracja wód i sufozja. Skala potencjalnych szkód może być duża, często mierzona w milionach metrów sześciennych (Patrzyk, 1996; Rybicki, 1996; Czarnecki, Organiściak, 2015). Wpływ na to ma szereg czynników związanych w dużym stopniu ze złożonością budowy geologiczno-inżynierskiej tych złóż, wieloma różnorodnmi czynnikami wewnętrznymi i zewnętrznymi inicjującymi osuwiska oraz stosunkowo niewielką częstotliwością wykonywanych pomiarów i badań kontrolnych.
Przeciwdziałanie zwykle ogranicza się do zmian w projektach eksploatacyjnych, geometrii zbocza, usypaniu przypór zwiększających ich stateczność lub zwiększeniu efektywności odwodnienia. Dla lepszego poznania genezy tych procesów, ich zasięgu, dalszej aktywności oraz skutecznej remediacji szczególne znaczenie ma zastosowanie komplementarnych metod badawczych in situ i laboratoryjnych (Bednarczyk, Sandven 2004). Rozpoznanie ewentualnych zagrożeń wymaga szczegółowej znajomości budowy geologicznej i warunków geologiczno-inżynierskich. Dane te muszą być zidentyfikowane i scharakteryzowane jakościowo.

Kompleksowe rozpoznanie warunków geologicznych i hydrogeologicznych, takich jak np. rodzaj gruntów i skał występujących w otworach, oraz określenie reprezentatywnych parametrów, takich jak wytrzymałość na ścinanie, wielkość, głębokość i kierunek przemieszczeń gruntu, głębokość zwierciadła wód gruntowych, występujące ciśnienie porowe w gruncie, jest zazwyczaj bardzo złożone. Ma ono jednak podstawowe znaczenie dla określenia bezpieczeństwa odkrywek i zwałowisk nadkładu. Jest też ważne do określenia instrumentów, które powinny być uwzględnione w projekcie systemu monitoringu. Metody obserwacyjne moga być wykorzystane do sprawdzenia wielkości zarejestrowanych przemieszczeń w trakcie eks-

\footnotetext{
${ }^{1}$ Poltegor-Instytut, Instytut Górnictwa Odkrywkowego, ul. Parkowa 25, 51-616 Wrocław; zbyszbed@gmail.com
} 
ploatacji kopalni oraz zmian powierzchni terenu w stosunku do przewidywanych wcześniej na etapie projektowania.

W artykule przedstawiono wybrane metody monitoringu geotechnicznego oraz określono ich przydatność dla wczesnego ostrzegania o możliwych zagrożeniach. W ramach polskiej części projektu RFCS Slopes na zachodnim zboczu KWB Bełchatów zainstalowano pierwszy w Polsce system monitoringu wgłębnego on-line w odkrywkowym zakładzie górniczym. Wykonane prace obejmowały także monitoring powierzchniowy przemieszczeń z wykorzystaniem radarowej interferometrii satelitarnej w wysokiej rozdzielczości (PSI), skanowania lotniczego (UAV LiDAR), naziemnego (TLS) oraz modelowanie numeryczne.

\section{METODY MONITORINGU I ANALIZ STATECZNOŚCI ZBOCZY}

W polskich kopalniach węgla brunatnego od wielu lat są stosowane różnorodne metody monitoringu geotechnicznego. Opierają się one zarówno na metodach geodezyjnych, geofizycznych jak i geologiczno-inżynierskich. Oprócz standartowych naziemnych pomiarów geodezyjnych w ostatnich latach powszechnie stosowane są pomiary satelitarne i lotnicze z wykorzystaniem UAV oraz naziemne i lotnicze skanowanie radarowe. Metody geologiczno-inyżnierskie, takie jak standardowe pomiary inklinometryczne oraz pomiary głębokości występowania poziomu wód gruntowych, mogą zostać rozbudowane o pomiary ciśnień porowych w gruncie, zaawansowane metody monitoringu przemieszczeń wgłębnych z wykorzystaniem czujników MASW 3D, magnetometrów, ekstensometrów, czujników naprężeń i temperatury gruntu. Nowoczesna instrumentacja monitoringowa umożliwia dostęp on-line do rejestrowanych danych oraz automatyczne generowanie alarmów przy przekroczeniu wartości progowych. Tego typu urządzenia stosowane na kopalniach odkrywkowych są w wielu krajach miedzy innymi w USA, Australii, Kanadzie (Bednarczyk 2017b).

Wyniki monitoringu zastosowane w modelowaniu numerycznym mogą pomóc w przewidywaniu przyszłego zachowania osuwisk w odkrywkowych zakładach górniczych. Dotyczy to zarówno wprowadzenia do modelu lokalizacji wykrytej powierzchni poślizgu osuwiska, wielkości przemieszczeń, położenia zwierciadła wód gruntowych, jak i ciśnienia porowego.

Modelowanie stateczności zboczy umożliwiają metody oparte na teorii równowagi granicznej, badające zależności pomiędzy siłami sprzyjającymi przemieszczeniom wgłębnym i siłami im przeciwdziałającymi. Tego typu metody, poza wartością wskaźnika stateczności zbocza Fos, nie wskazują ryzyka związanego z danym scenariuszem (Nguyen, i Chowdhury 1984, Wu 2008). Współczynnik stateczności zbocza jest określany jako:

$$
\text { Fos }=\frac{\operatorname{tg} \varphi}{\operatorname{tg} \varphi_{f}}=\frac{c}{c_{f}}
$$

gdzie:

$\varphi$ - kąt tarcia wewnętrznego materiału budującego zbocze [deg],

$\varphi_{f}-$ kąt tarcia wewnętrznego materiału budującego zbocze, przy którym traci ono stateczność [deg],

$c$ - spójność materiału budującego zbocze [MPa], $c_{f}$ - spójność materiału budującego zbocze, przy którym traci ono stateczność [MPa].

W analizach wykorzystujących metody analizy granicznej badanie ogranicza się do oceny stateczności i nie zawiera informacji o lokalnych warunkach, które doprowadziły do powstania osuwisk. Postęp w dziedzinie mechaniki gruntów i programów komputerowych umożliwił zastosowanie bardziej kompleksowych metod, np. opartych na teorii elementów skończonych FEM i teorii redukcji wytrzymałości na ścinanie SSR. Jednakże często najbardziej rozpowszechnione praktyki są oparte na podejściu deterministycznym. Niedogodnością podejścia konwencjonalnego jest fakt, że czynniki wpływające na globalne lub częściowe współczynniki stateczności oraz wyniki analiz nie w pełni wiarygodnie odzwierciedlają współczynnik stateczności Fos skarpy, jako całej struktury geotechnicznej (Baecher, Christian 2003; Ang, Tang, 2007). Według Whitmana (1984) współczynniki stateczności Fos wskazują jedynie na możliwość wystąpienia osuwiska. Może to być mylące przy określaniu rzeczywistego poziomu ryzyka. Lokalnie wysokie współczynniki stateczności Fos niekoniecznie odzwierciedlają niższy poziom ryzyka, ponieważ ich wyniki mogą być zanegowane przez inne wattpliwości, słabości w rozpoznaniu terenowym lub niewystarczającą liczbę analiz (Christian, Ladd, 1994). Niedogodności te mogą stanowić istotne ryzyko ekonomiczne przy projektowaniu odkrywek. Identyfikacja reprezentatywnych parametrów wytrzymałościowych oraz eliminacja błędów wpływających na niepewność przyjętych założeń projektowych jest bardzo ważna dla zachowania bezpieczeństwa geotechnicznego (Kulhawy, 1992; Phoon, Kulhawy, 1999). W Polsce są stosowane różnorodne metody modelowania stateczności zboczy jednak nie zawsze są one powiązane $\mathrm{z}$ wynikami monitoringu. W ostatnich latach obserwuje się tendencję do wdrażania metod projektowania przyjętych przez Eurokod 7, uwzględniających zmienność parametrów geotechnicznych (CEN, 1994).

\section{CHARAKTERYSTYKA GEOLOGICZNA OBSZARU BADAŃ}

Badania przeprowadzono w kopalni odkrywkowej KWB Bełchatów, która jest jednym z największych wyrobisk odkrywkowych w Europie, położonym $30 \mathrm{~km}$ na południowy wschód od Łodzi (ryc. 1). Wymiary kopalni to $12,5 \mathrm{~km}$ długości i 3 km szerokości. Aktualna głębokość wydobycia wynosi $310 \mathrm{~m}$.

Złoże węgla brunatnego Bełchatów jest położone w obrębie rowu tektonicznego Kleszczowa, który powstał w podłożu górnokredowych i jurajskich wapieni oraz margli, jako wąska i głęboka struktura tektoniczna o kierunku W-E, wypełniona osadami neogeńskimi (ryc. 2a). Od strony południowej i północnej rów jest ograniczony dużymi uskokami brzeżnymi. Bloki mezozoiczne wewnątrz rowu są rozdzielone poprzecznymi uskokami. Kopalnia prowadzi wydobycie węgla brunatnego na dwóch polach eksploatacyjnych, rozdzielonych wysadem solnym. Miąższość osadów neogeńskich w obrębie rowu przekracza $300 \mathrm{~m}$ i jest ok. 5-15 razy większa niż poza nią (Ciuk, Piwocki 1980). Główny pokład węgla brunatnego ma miąższość 20-60 m. Największe ilości węgla brunatnego znajdują się w głębokim rowie drugiego rzędu w pobliżu południowego stoku kopalni (ryc. 2b). Eksploatacja złoża Bełchatów zakończy się w ciągu kilku najbliższych lat, a złoża Szczerców 


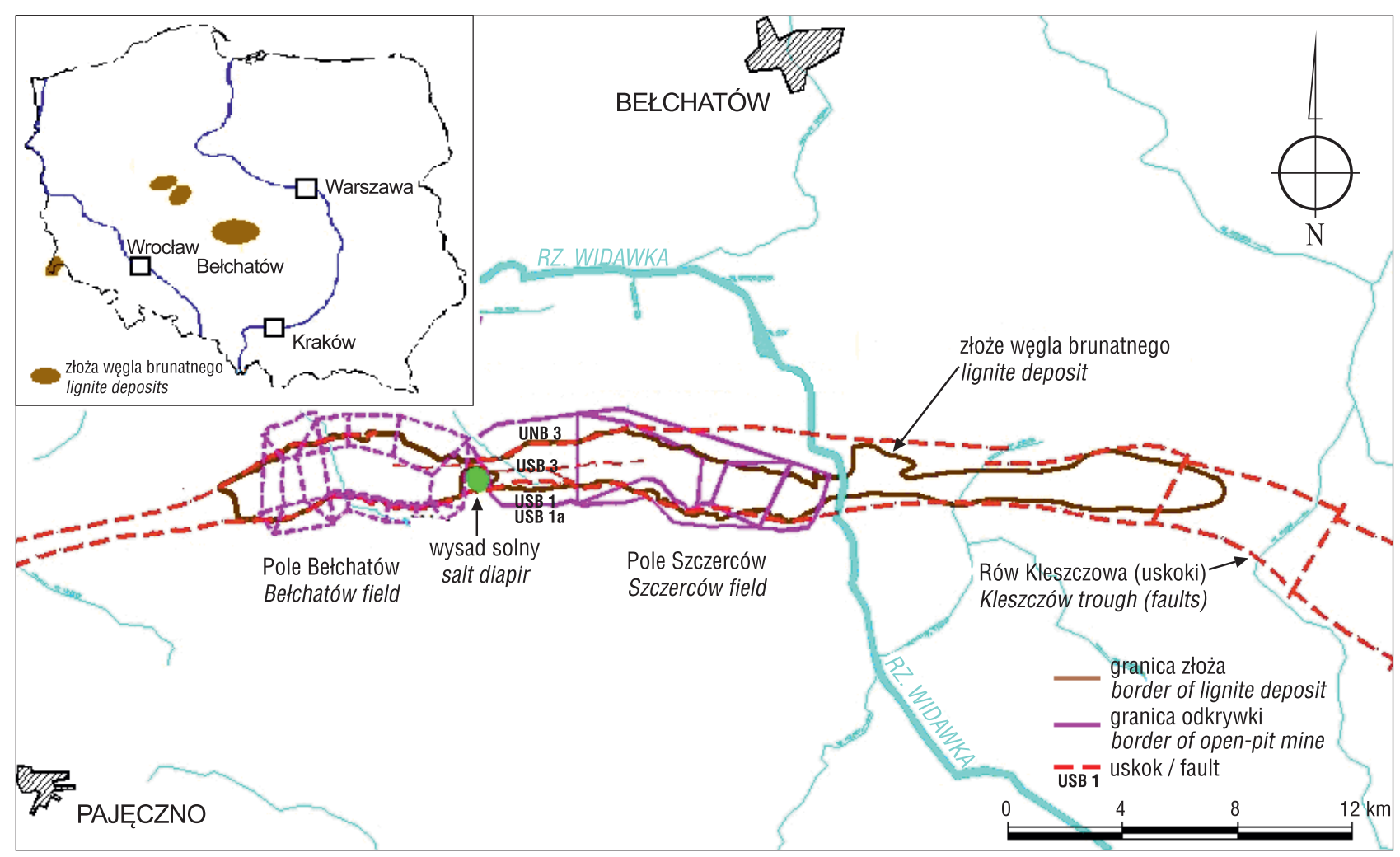

Ryc. 1. Lokalizacja KWB Bełchatów

Fig. 1. The Betchatów Mine location

w 2038 r. Niskie parametry wytrzymałościowe gruntów ilastych nadkładu oraz złożona struktura tektoniczna o głębokości ponad $300 \mathrm{~m}$ powodują poważne zagrożenia dla stateczności zboczy. Corocznie odnotowuje się tu kilkaset małych i dużych osuwisk o objętości setek, a nawet kilku milionów metrów sześciennych (Patrzyk, 1996; Rybicki, 1996; Janecki i in., 1999; Jonczyk, Organiściak, 2010). W 2012 r. wykryto 32 strefy zagrożenia na zboczach. Ponad $85 \%$ osuwisk spowodowanych eksploatacją górniczą miało charakter strukturalny (Flisiak i in., 2014). Na wybranym do badań Polu Bełchatów wystąpiło wiele groźnych osuwisk o objętości od kilku tysięcy do $3,5 \mathrm{mln} \mathrm{m}^{3}$, z przemieszczeniami od $2 \mathrm{~mm}$ do $2 \mathrm{~m}$ na dobę (Rybicki, 1996; Jonczyk, Organiściak, 2010; Czarnecki, Organiściak, 2015). Podatne na osuwiska powierzchnie strukturalne i paleosuwiskowe występują na południowym zboczu wyrobiska, w pobliżu głębokiej wtórnej struktury zapadliskowej o największej miąższości węgla brunatnego. Północne zbocze tej kopalni zbudowane z czwartorzędowych iłów zastoiskowych i warwowych o małej wytrzymałości stwarzało również liczne zagrożenia dla linii transportu taśmowego i infrastruktury energetycznej. Głównymi powierzchniami strukturalnymi narażonymi na osuwiska są granice osadów czwartorzędowych i neogeńskich, granice iłów neogeńskich oraz strop głównego pokładu węgla brunatnego. Innymi powierzchniami podatnymi na powstawanie osuwisk są uskoki, spękania, powierzchnie tektoniczne i glacitektoniczne, grunty o niskiej wytrzymałości oraz iły neogeńskie. Obserwuje się znaczną przewagę osuwisk strukturalnych, które są naturalną konsekwencją złożoności budowy geologicznej złoża węgla brunatnego i nadkładu. Największe osuwiska wystąpiły na południowym zboczu odkrywki, wzdłuż uskoków zlokalizowanych na tym zboczu. Występujący tam, uskok USB1 (ryc. 1, 2b) występuje na całej długości odkrywki, natomiast uskok
USB1a nie wszędzie jest wyraźny. Według Kossowskiego i innych (1992) USB1 jest wąską strefą uskokową, która stanowi górny koniec głębokiej, wklęsłej dyslokacji o przebiegu $\mathrm{W}-\mathrm{E}$, związanej z okresem waryscyjskim. Od północy złoże jest ograniczone uskokiem UNB3 o charakterze komplementarnym do wyżej wymienionych uskoków. W południowej części rowu Kleszczowa występuje struktura rowu drugiego rzędu. Jest to wąska i głęboka strefa ograniczona od południa uskokami USB1 i USB1a, a od północy uskokiem USB2 (ryc. 2b). Struktura ta, o dużo większej głębokości, ma przebieg zgodny z głównym kierunkiem rowu Kleszczowa. Charakteryzuje się występowaniem osadów paleosuwiskowych, podatnych na aktywację przemieszczeń. W ostatnich latach, ze względu na dużą głębokość eksploatacji węgla brunatnego oraz sąsiadującą strukturę wysadu solnego, również zbocze zachodnie Pola Bełchatów zostało objęte ruchami osuwiskowymi. Na tym zboczu odnotowano osiem stref zagrożeń osuwiskowych z aktywnymi lub spodziewanymi przemieszczeniami. Zbocze to zostało wybrane do badań prowadzonych w ramach polskiej części projektu EU RFCS Slopes, których wyniki przedstawiono w niniejszym artykule.

\section{METODY I WYNIKI MONITORINGU}

\section{LiDAR}

Metodyka. W projekcie Slopes do budowy numerycznego modelu terenu W KWB Betchatów wykorzystano pomiary LiDAR UAV przy użyciu skanera YellowScan (ryc. 3). Pomiary przeprowadzono w październiku i listopadzie 2016 r. Do analizy przemieszczeń na zboczu zachodnim wykorzystano także lotnicze pomiary LiDAR z marca 2017 r. Po zakończeniu skanowania dane ze skanera zostały zczytane do programu analizującego wyniki badań, gdzie 


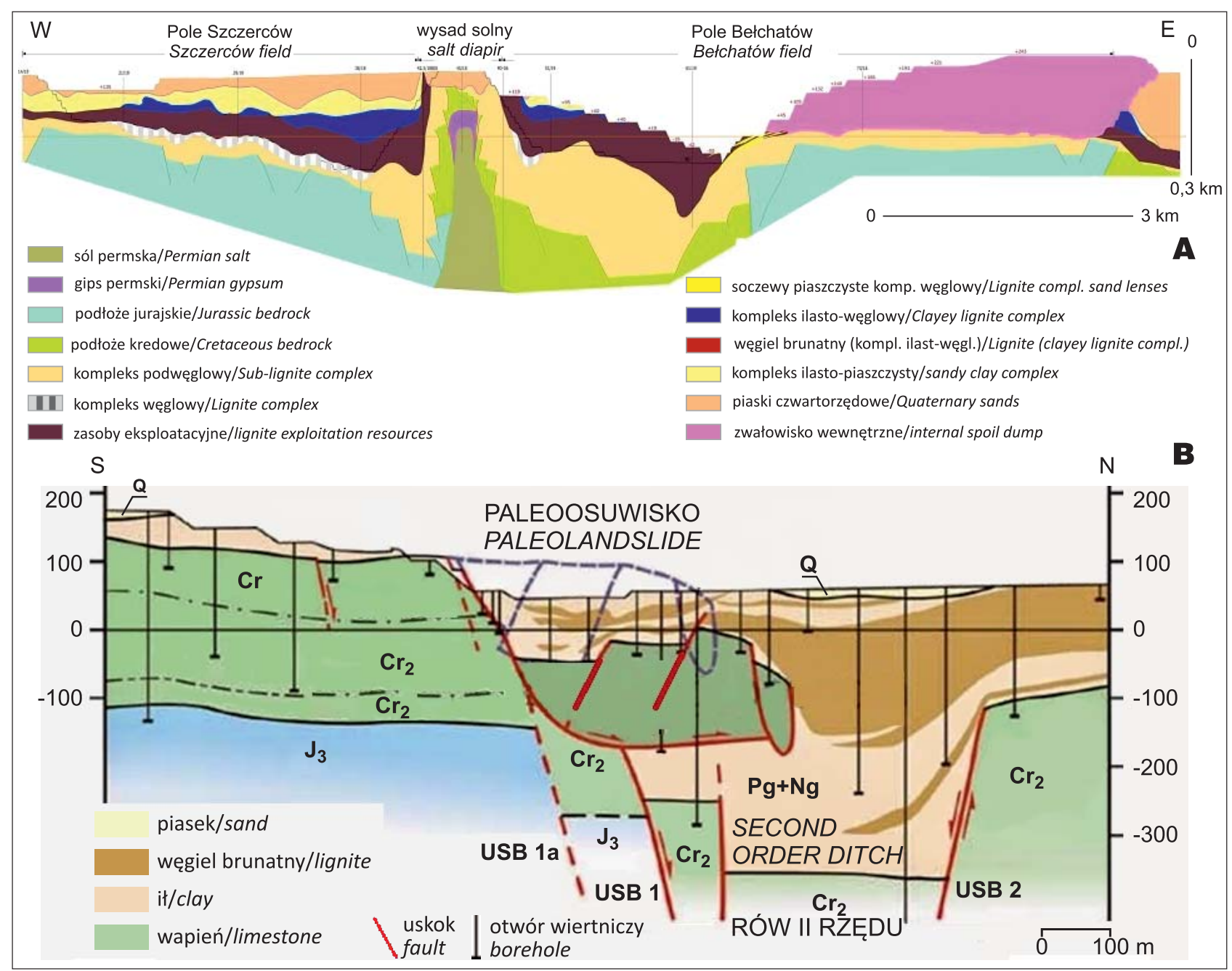

Ryc. 2. Przekrój geologiczny W-E złoża Bełchatów (A), przekrój geologiczny S-N strefy rowu drugiego rzędu (B) (Czarnecki, Felisiak, 2004)

Fig. 2. W-E geological cross-section, Bełchatów Mine deposit (A), S-N second-order ditch geological cross-section (B) (Czarnecki, Felisiak, 2004)

dokonano ich wizualizacji (w postaci chmur punktów) i zidentyfikowano błędy, w celu ustalenia, czy konieczne będą dodatkowe loty. Następnie były one przetwarzane w post-processingu kinematycznym, wyeliminowano szumy pomiarowe, scalono linie pomiarowe oraz oznaczono zdjęcia w siatce 3D. Umożliwiło to stworzenie ortofotomapy. Do kalibracji wyników wykorzystano 11 naziemnych punktów kontrolnych GCP (Ground Control Points). Wygenerowana chmura punktów o gęstości wahała się od 250 do 300 punktów $/ \mathrm{m}^{2}$ i obejmowała ponad 29,6 mln punktów.

Wyniki. Wyniki skanowania LiDAR z drona oraz zdjęć lotniczych w okresie od listopada 2016 r. do marca 2017 r. przedstawiono na rycinie 3, na którym są widoczne przemieszczenia i nieciągłości na zachodnim zboczu Pola Bełchatów. W celu potwierdzenia i oceny wielkości przemieszczeń w programie Cloud Compare integrowano wyniki kolejnych pomiarów. W ten sposób potwierdzono występowanie przemieszczeń na zachodnim zboczu.

Obszary przemieszczeń zboczu zachodnim na rycinie 5 zaznaczono kolorem od zielonego do czerwonego, z odpowiadającymi im wartościami przemieszczeń szacowanymi na ok. $6 \mathrm{~mm}$. Badania z użyciem LiDAR wykryły kilka obszarów przemieszczeń na zboczu zachodnim, w jego północnej części (ryc. 3). Uzyskane wyniki pozwoliły na wydzielenie kilku obszarów przemieszczeń, w tym osuwiska w pobliżu punktu monitoringu in situ na poziomie $42 \mathrm{~m}$ n.p.m.

\section{Naziemny skaning laserowy}

Metodyka. Naziemny skaning laserowy zachodniego zbocza Pola Bełchatów został przeprowadzony w czerwcu 2016 r. przez Uniwersytet Exeter (Wielka Brytania). Pomiary przeprowadzono przy użyciu skanera laserowego Rigel-VZ4000. Skaner umiejscowiono w czterech miejscach na zboczu południowym Pola Bełchatów oraz dwóch na zboczu północnym. Na podstawie tych danych utworzono numeryczny model terenu (ryc. 4). Wyniki skanowania posłużyły również do określenia kąta nachylenia i kierun$\mathrm{ku}$ geograficznego zbocza przy użyciu oprogramowania ArcGIS.

Wyniki. Wyniki tych analiz, przedstawione na rycinie 4, wskazały, że kąty nachylenia poszczególnych zboczy wahają się od kilku do ok. $70^{\circ}$. W celu identyfikacji stref osuwiskowych porównano również wyniki naziemnego skaningu laserowego TLS z wynikami późniejszego skanowania LiDAR UAV z listopada 2016 r. oraz fotogrametrii lotniczej z marca 2017 r. (ryc. 5A, B). Na modelach 


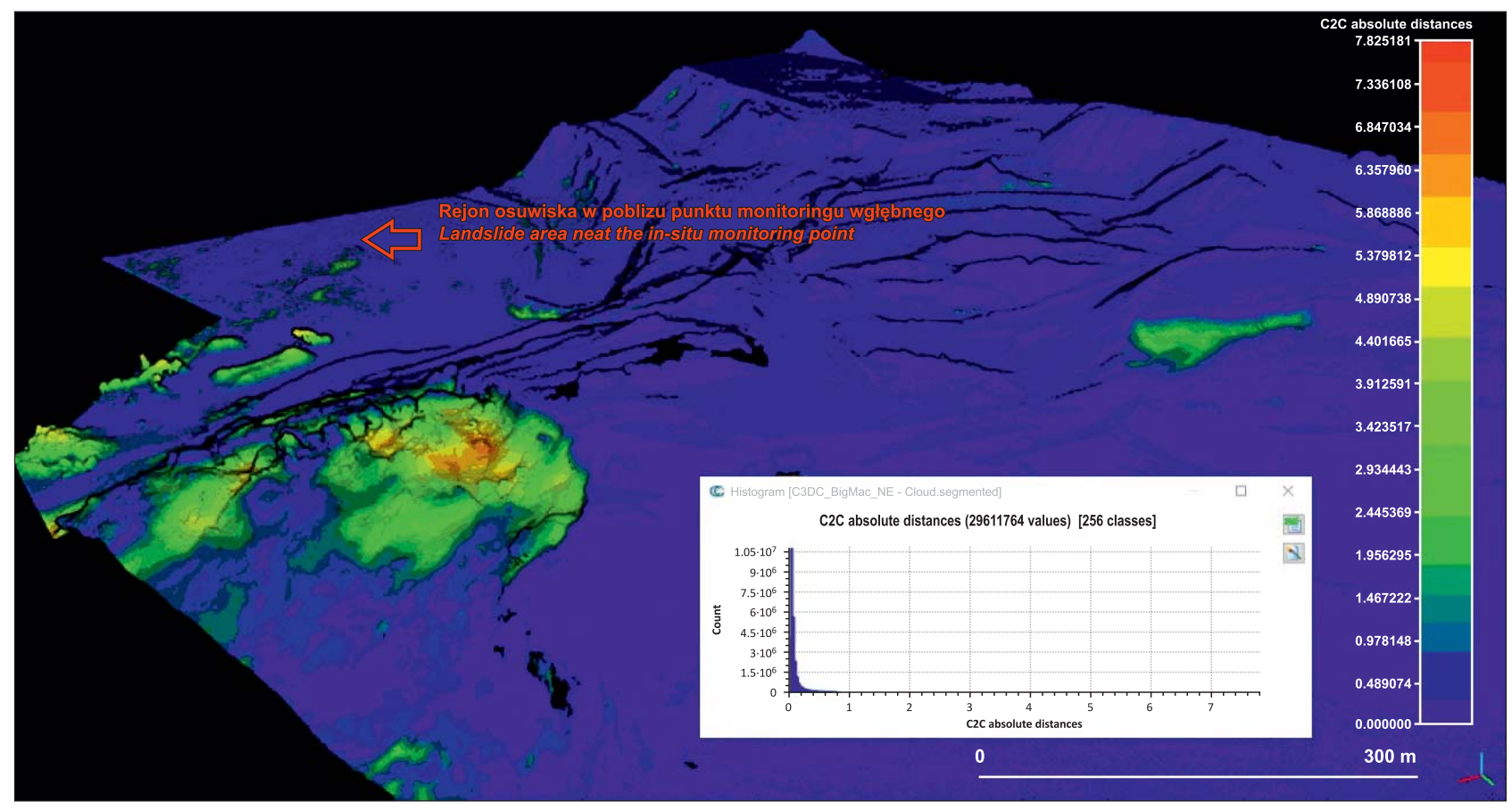

Ryc. 3. Porównanie pomiarów LiDAR UAV z fotogrametrią lotniczą, przemieszczenia po trzech miesiącach (listopad 2016-marzec 2017) część północna zbocza zachodniego Pola Bełchatów, Ineris (Francja). Źródło: Slopes project report (Marshall i in., 2019) Fig. 3. Comparison of LiDAR UAV measurements with aerial photogrammetry, displacement after three months (November 2016-March 2017) north part of west slope in Bełchatów Field, Ineris (France). Source: Slopes project report (Marshall et al., 2019)
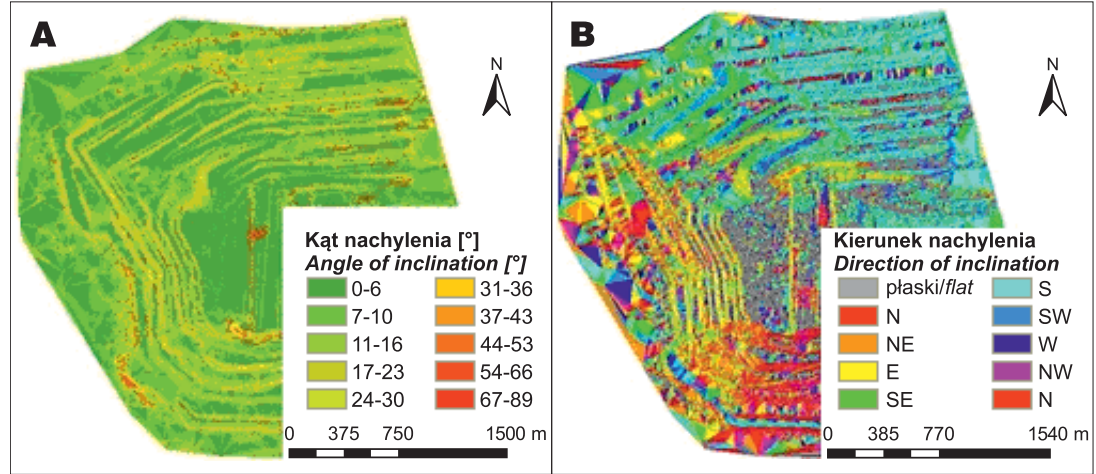

Ryc. 4. Interpretacja kąta nachylenia (A) i kierunku nachylenia (B) zbocza zachodniego Pola Bełchatów na podstawie skaningu laserowego TLS, University of Exeter (UK) Źródło: Slopes project report (Marshall i in., 2019)

Fig. 4. Interpretation of angle of inclination (A) and direction of inclination at west slope (B) of the Bełchatów Field based on TLS laser scanning, University of Exeter (UK). Source: Slopes project report (Marshall et al., 2019)

wyraźnie widać czerwone i zielone strefy reprezentujące największe przemieszczenia na niebieskim tle reprezentującym obszary stabilne.

\section{Satelitarna Interferometria Radarowa (PSI)}

Metodyka. Satelitarne skanowanie radarowe w wysokiej rozdzielczości PSI (Persistent Scatterer Interferometry) z satelitów Cosmo SkyMed (dokładność 5-10 mm) zostało zamówione przez Poltegor-Instytut i wykonane przez GAP Geophysical Applications Processing s.r.l. (GAP Spółka zależna Politechniki Bari, Włochy). Technika zastosowana do tego uzupełniającego monitoringu opierała się na interferometrii SAR (Synthetic Aperture Radar) z wykorzystaniem satelity COSMO-SkyMed, z użyciem oprogramowania SPINUA (Stable Points Identification in Non-Urbanized Area). Jest to program przetwarzania obrazu interferome- trycznego SAR dla monitorowania przemieszczeń gruntu (ryc. 6). Oprogramowanie to pozwala na systematyczne przetwarzanie wszystkich zarchiwizowanych danych z danego obszaru, poprzez tworzenie interferogramów różnicowych, które analizują obraz główny w funkcji czasu i przestrzeni. Techniki PSI omijają problem korelacji geometrycznej i czasowej poprzez uwzględnienie czasowo koherentnych rozpraszaczy. Ponadto, dzięki wykorzystaniu dużej ilości danych, sygnał jest szacowany i korygowany. Program umożliwia wykorzystanie wszystkich pozyskanych obrazów (niezależnie od linii bazowej) oraz estymację parametrów dla interferogramów o niskiej spójności przestrzennej.

Satelita COSMO-SkyMed (Constellation of Small Satellites for Mediterranean Basin Observation) jest największym włoskim satelitą kosmicznym. System składa się z czterech średniej wielkości satelitów umieszczonych na niskiej orbicie okołoziemskiej. Każdy satelita jest wyposażony w wielomodowy radar SAR, o wysokiej rozdzielczości, pracującym w paśmie $X$, rozmieszczonym w sposób rozłożony w czasie. Dziesięciokrotne zwiększenie rozdzielczości zasięgu naziemnego (w odniesieniu do danych ERS/ENVISAT/Sentinel-1) oraz krótszy cykl powtarzania orbity (16 dni dla pojedynczego satelity konstelacji COSMO-SkyMed, 4 dni dla całej konstelacji COSMO-SkyMed w stosunku do 35 dni dla ERS/ENVISAT) przyczyniło się poprawy możliwości monitorowania poprzez instrumenty teledetekcji. Badania dotyczyły całego terenu KWB Bełchatów, $\mathrm{w}$ tym badanego rejonu zbocza zachodniego Pola Bełchatów oraz rejonów przyległych. Analizowany obszar objęty skanowaniem miał wymiary ok. $30 \times 30 \mathrm{~km}$. Skano- 

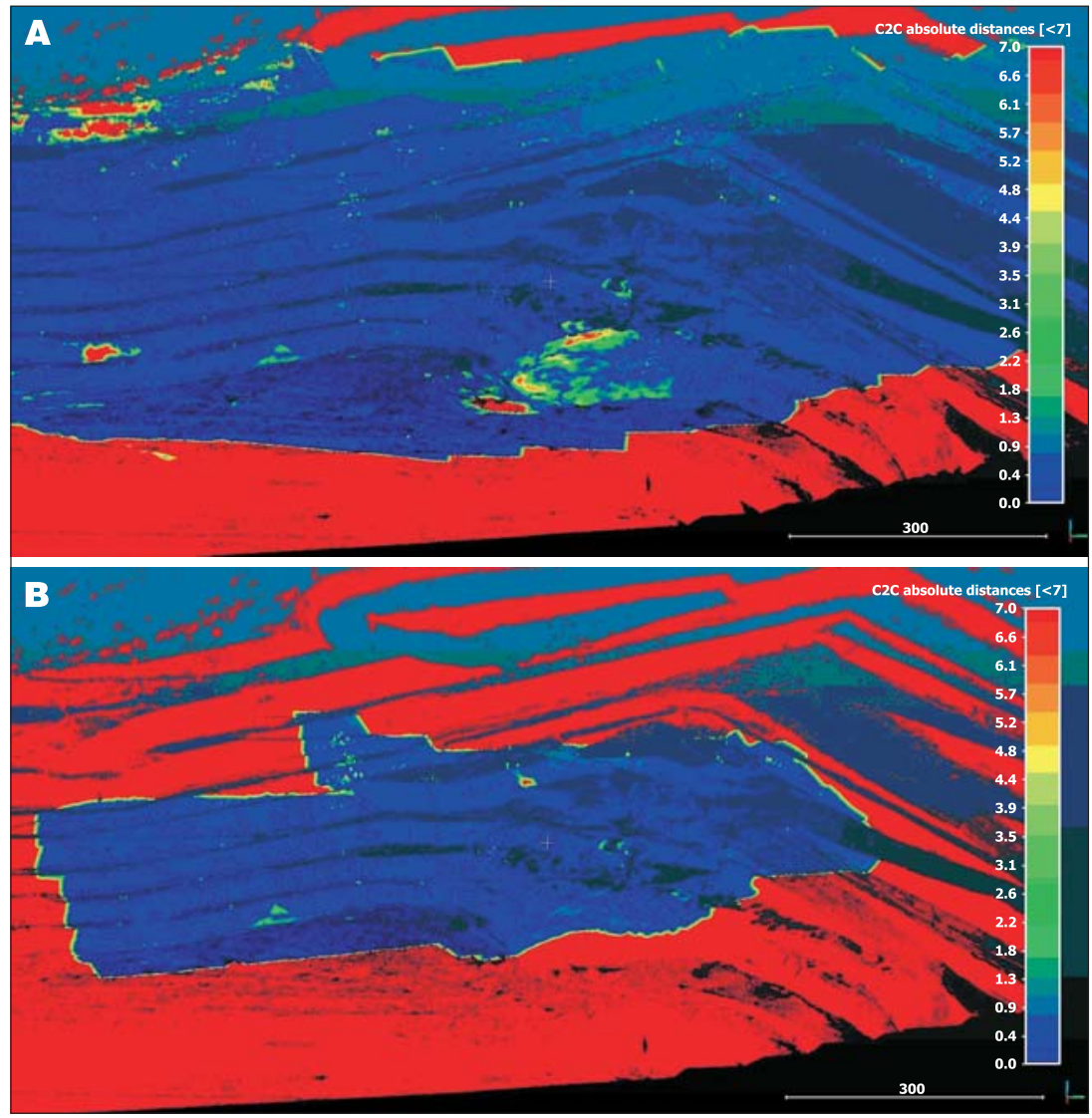

Ryc. 5. Porównanie fotogrametrii lotniczej z pomiarami LiDAR UAV przemieszczenia po trzech miesiacach listopad 2016-marzec 2017 (A) i wynikami naziemnego skaningu laserowego TLS czerwiec 2016-marzec 2017 (B), zachodnie zbocze pola Bełchatów część północna, Ineris (Francja). Źródło: Slopes project report (Marshall i in., 2019)

Fig. 5. Comparison of aerial photogrammetry with LiDAR UAV measurements, displacement after three months November 2016March 2017 (A) and aerial TLS scanning June 2016-March 207 (B), north part of west slope in Bełchatów Field, Ineris (France). Source: Slopes project report (Marshall et al., 2019)

\section{Schemat działania programu Spinua}

\section{Spinua software operating scheme}

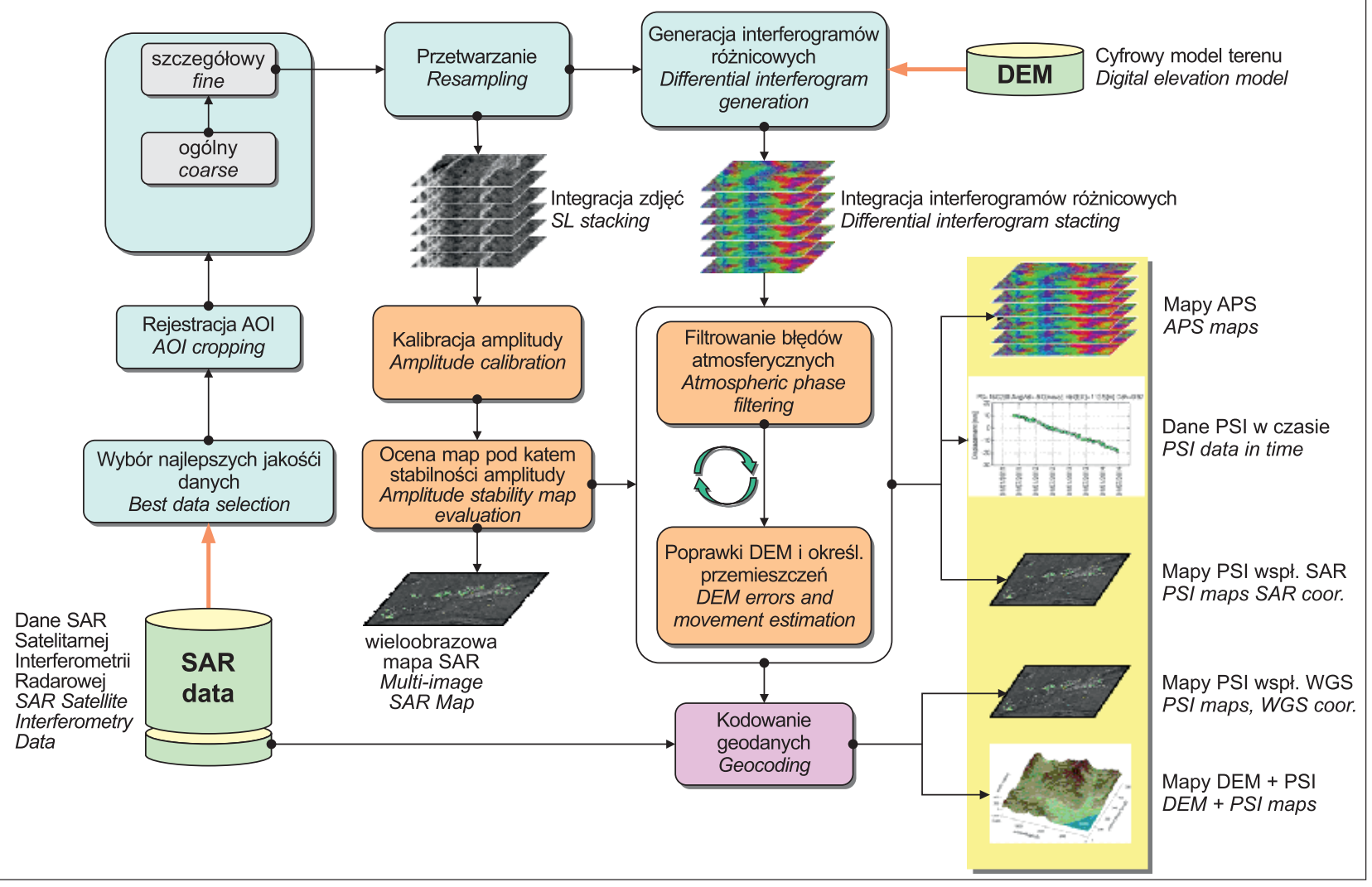

Ryc 6. Schemat blokowy oprogramowania Spinua

Fig. 6. Flow chart of Spinua software 


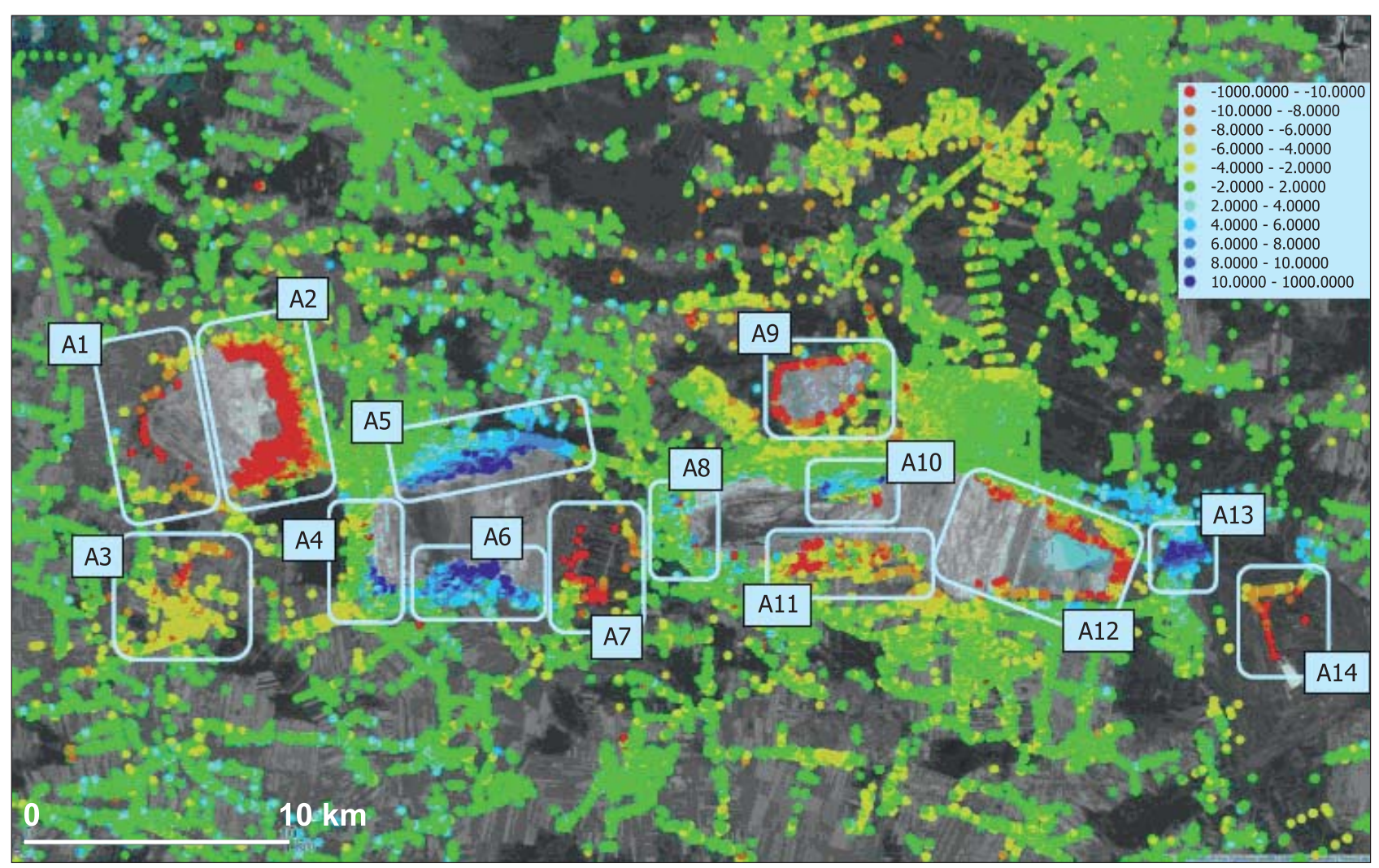

Rys. 7. Wyniki interferometrami satelitarnej Persistent Scatter Interferometry (PSI). Pola A1-A14 - rejony zagrożeń (przemieszczeń); A1-A3 - zwałowisko zewn. Pola Szczerców; A4-A7 - Pole Szczerców; A8 - wysad solny Dębiny; A8, A10-A11 - Pole Bełchatów; A9 - osadnik popiołów z elektrowni; A12 - zwałowisko wewnętrzne Pola Bełchatów; A13 - składowisko popiołów z elektrowni; A14 zwałowisko zewnętrzne Pola Bełchatów; wielkości przemieszczeń (-) maks. osiadania - kolor czerwony, maks. wypiętrzenia kolor ciemnoniebieski, legenda w prawym górnym rogu rysunku [mm]

Fig. 7. Results of Persistent Scatter Interferometry (PSI). Fields A1-A14 - risk areas (displacements); A1-A3 - external spoil dump of Szczerców Field; A4-A7 Szczerców Field; A8 Dębina Salt Dome; A8, A10-A11 Bełchatów Field; A9 - settling ash power plant tank; A12 - internal spoil dump of Bełchatów Field; A13 - power plant ash dump; A14 - external dump of Bełchatów Field; displacement values (-) max. subsidence - red color, max. uplift - dark blue color, legend in the upper right corner of the drawing [mm]

wanie SAR COSMO-SkyMed wykonywano w trybie STRIPMAP, uzyskując obrazowanie o średniej rozdzielczości, z dwoma radarami w geometrii wznoszącej o rozdzielczości przestrzennej $3 \mathrm{~m}$.

Wyniki. Wstępne wyniki PSI składają się z mapy przemieszczeń powierzchniowych, która zawiera jedynie zidentyfikowaną ich średnią prędkość (ryc. 7). Pomimo tego że wstępna obróbka bazowała na ograniczonej liczbie punktów, to udało się znaleźć 100 tys. wiarygodnych punktów pomiarowych na terenie KWB Bełchatów i w jej pobliżu (obszar ok. $1600 \mathrm{~km}^{2}$ ), dzięki którym możliwe było określenie prędkości przemieszczeń powierzchniowych. Prędkości przemieszczeń są obliczone w stosunku do pozycji satelity: wartości dodatnie (punkty niebieskie) odpowiadają punktom poruszającym się w kierunku satelity, natomiast wartości ujemne (punkty czerwone) odpowiadają punktom oddalającym się od satelity. Punkty poruszające się ortogonalnie do linii wzroku są ,widziane” przez satelitę jako punkty nieruchome. Szczegółowy widok badanego rejonu KWB Bełchatów przedstawiono w postaci mapy, na której dla lepszego zobrazowania przemieszczeń zastosowano różne kolory (ryc. 7). Można zauważyć, że największe osiadania (kolor czerwony) wystąpiły na zewnętrznym zwałowisku nadkładu Pola Szczerców, na wewnętrznym zwałowisku nadkładu Pola Bełchatów oraz na wewnętrznym składowisku popiołów z elektrowni. Największe wypiętrzenia, prawdopodobne zmiany morfologii zbocza (kolor niebieski) związane z ruchami osuwiskowymi, wystapiły na północnym i południowym zboczu Pola Bełchatów. Używając zdefiniowanej skali do $50 \mathrm{~mm}$ rocznie, można wnioskować, że największe osiadania (kolor czerwony) wystąpiły na zewnętrznym zwałowisku Pola Szczerców i górnej części zwałowiska wewnętrznego Pola Bełchatów. Natomiast przy skali do $100 \mathrm{~mm}$ rocznie obszary te (czerwone punkty) ograniczały się do zewnętrznego zwałowiska Pola Szczerców.

Wykorzystując zdjęcia satelitarne CosmoSkyMed, dla całego obszaru KWB Bełchatów i obszarów przyległych zidentyfikowano 781206 punktów, dla których określono przemieszczenia powierzchniowe. Łącznie zidentyfikowano czternaście stref przemieszczeń w obrębie zewnętrznego zwałowiska nadkładu Pola Szczerców oraz w kilku innych rejonach, w tym na zboczach odkrywek Pola Bełchatowa i Szczercowa. Największe osiadania, dochodzące do $60 \mathrm{~mm} / \mathrm{rok}$, stwierdzono na wschodnim zboczu zewnętrznego zwałowiska nadkładu Pola Szczerców. Na zachodnim zboczu tego zwałowiska osiadania wynosiły 30-40 mm/rok. W rejonie południowego zbocza Pola Bełchatów przemieszczenia (punkty porównywalne) wynosiły 19-24 mm/rok.

Na zboczu zachodnim przemieszczenia powierzchniowe stwierdzone metodą satelitarną wynosiły do $10 \mathrm{~mm} / \mathrm{rok}$ i były znacząco mniejsze niż wyniki wgłębnego monitoringu inklinometrycznego, wynoszące ok. $100 \mathrm{~mm} /$ rok do 
Tab. 1. Wyniki badań trójosiowych

Table 1. Results of triaxial tests

\begin{tabular}{|c|c|c|c|c|c|c|c|}
\hline \multirow{3}{*}{$\begin{array}{l}\text { Lp. } \\
\text { No. }\end{array}$} & \multirow{3}{*}{$\begin{array}{c}\text { Glębokość } \\
\text { Depth } \\
\text { [m] }\end{array}$} & \multirow{3}{*}{$\begin{array}{l}\text { Typ gruntu } \\
\text { Soil type }\end{array}$} & \multirow{3}{*}{$\begin{array}{l}\text { Rodzaj testu } \\
\text { Test type }\end{array}$} & \multicolumn{4}{|c|}{$\begin{array}{c}\text { Parametry wytrzymalościowe } \\
\text { Strength parameters }\end{array}$} \\
\hline & & & & \multicolumn{2}{|c|}{$\begin{array}{c}\text { Kąt tarcia wewnętrznego } \\
\text { Friction angle }\end{array}$} & \multicolumn{2}{|c|}{$\begin{array}{l}\text { Spójność } \\
\text { Cohesion }\end{array}$} \\
\hline & & & & $\phi[\operatorname{deg}]$ & $\phi^{\prime}[\mathrm{deg}]$ & $\mathrm{c}[\mathrm{kPa}]$ & $\mathrm{c}^{\prime}[\mathrm{kPa}]$ \\
\hline 1 & 4,0 & $\begin{array}{l}\text { piasek gliniasty } \\
\text { loamy sand }\end{array}$ & CIU & 42,9 & 42,9 & 0,0 & 0,0 \\
\hline 2 & 16,4 & $\begin{array}{l}\text { pył piaszczysty } \\
\text { sandy silt }\end{array}$ & CIU & 33,5 & 34,1 & 27,8 & 19,7 \\
\hline 3 & 29,3 & $\begin{array}{l}\text { glina } \mathrm{z} \text { dom. węgla } \\
\text { brunat. } \\
\text { clay with an admixture } \\
\text { of brown coal }\end{array}$ & $\mathrm{CIU}$ & 11,4 & 14,5 & 66,3 & 103,2 \\
\hline 4 & 33,0 & $\begin{array}{l}\text { ił pylasty } \\
\text { silty clay }\end{array}$ & $\mathrm{CIU}$ & 21,8 & 30,3 & 129,2 & 32,5 \\
\hline 5 & 33,5 & $\begin{array}{l}\text { węgiel brunatny } \\
\text { brown coal }\end{array}$ & CID & & 19,0 & & 200,0 \\
\hline 6 & 46,4 & $\begin{array}{l}\text { if } \\
\text { clay }\end{array}$ & CIU & 8,5 & 9,8 & 6,3 & 18,7 \\
\hline 7 & 47,5 & $\begin{array}{l}\text { piasek gliniasty } \\
\text { loamy sand }\end{array}$ & $\mathrm{CIU}$ & 25,1 & 28,6 & 0,0 & 0,0 \\
\hline 8 & 50,5 & $\begin{array}{l}\text { ił } \\
\text { clay }\end{array}$ & CIU & 12,9 & 15,5 & 373,0 & 345,1 \\
\hline 9 & 57,5 & $\begin{array}{l}\text { piasek gliniasty } \\
\text { loamy sand }\end{array}$ & CIU & 29,1 & 28,4 & 0,0 & 0,0 \\
\hline 10 & 81,0 & $\begin{array}{l}\text { pył piaszczysty } \\
\text { sandy silt }\end{array}$ & CIU & 35,3 & 34,9 & 32,3 & 41,2 \\
\hline 11 & 81,5 & $\begin{array}{l}\text { pył piaszczysty } \\
\text { sandy silt }\end{array}$ & $\mathrm{CIU}$ & 32,3 & 32,4 & 154,9 & 153,6 \\
\hline
\end{tabular}

głęb. $40 \mathrm{~m}$ (w zakresie $+42 /-2 \mathrm{~m}$ n.p.m.). Prawdopodobnie było to spowodowane faktem, że satelita poruszał się w tym samym kierunku, co występujące przemieszczenia (z zachodu na wschód).Wydaje się, że takim przypadku celowe by było umieszczenie specjalnych reflektorów zlokalizowanych w rejonie punktu pomiarów inklinometrycznych, które umożliwiłyby lepszą widoczność przemieszczeń powierzchni terenu przez satelitę. Należy także zaznaczyć, że wyniki monitoringu powierzchniowego nie zawsze są zgodne $\mathrm{z}$ wielkościami przemieszczeń wgłębnych występujących na dużych głębokościach i reprezentujących zmienne wartości przemieszczeń.

Zaletą pomiarów satelitarnych PSI było to, że umożliwiły one analizę przemieszczeń na dużym obszarze obejmującym cały zakład górniczy i tereny do niego przyległe. Należy zaznaczyć, że metoda ta pozwala na badanie przemieszczeń inicjujących większe osuwiska i ich dalszy rozwój. Ma jednak również ograniczenia związane z miejscami, gdzie morfologia zmienia się bardzo szybko i nie pozwala na porównywanie tych samych elementów terenu. W takich przypadkach przemieszczenia mogą wynosić np. do $1000 \mathrm{~mm} /$ dobę, dla nowo składowanych gruntów na zwałowiskach nadkładu (wtedy brak jest danych satelitarnych). Podobną sytuację z brakiem danych można zaobserwować na bardzo aktywnych osuwiskach o dużych przemieszczeniach, szybko zmieniających swoją morfologię (np. osuwisko na południowym zboczu Pola Bełchatów). W takich przypadkach pomocne w pomiarach mogłyby być reflektory zainstalowane na stałe na powierzchni zboczy w zagrożonych rejonach.

\section{Badania laboratoryjne}

Metodyka. Zainstalowanie systemu monitoringu wymagało wykonania wierceń rdzeniowych, pobrania próbek oraz szczegółowego opisu geologiczno-inżynierskiego rodzajów gruntów, ich wilgotności, konsystencji oraz wstępnych, terenowych badań ich parametrów wytrzymałościowych.

Do rozpoznania podstawowych parametrów fizycznych i wytrzymałościowych gruntów pobrano 31 próbek NNS o średnicy $90 \mathrm{~mm}$ i długości 500-700 mm. Wstępną identyfikację parametrów wytrzymałościowych przeprowadzono na podstawie 36 polowych badań penetrometrem wciskowym i ścinarką obrotową. Badania wytrzymałości na ścinanie wykonane na próbkach gruntu $\mathrm{z}$ otworu wiertniczego wykazały spójność $(\mathrm{Cu}) 24-44,7$ kPa oraz wytrzymałość na ścinanie 23,9-47,8 kPa. Najniższe wartości parametrów wytrzymałościowych stwierdzono dla iłów na głębokości $54 \mathrm{~m}$, a najwyższe w glinach z węglem brunatnym na głębokości 29,5 m. Program badań laboratoryjnych obejmował badania podstawowych parametrów fizycznych gruntów, badanie w aparacie bezpośredniego ścinania, badania edometryczne, trójosiowe CIU oraz CID. Badania podstawowych parametrów fizycznych gruntów obejmowały analizę uziarnienia, wilgotności, gęstość objętościową, gęstość objętościową szkieletu gruntowego w stanie suchym i nasyconym wodą. Badania obejmowały również zawartość części organicznych oraz granice płynności i plastyczności.

Testy trójosiowe wykonano na 31 próbkach gruntu pobranych z otworu wiertniczego dla rozpoznania budowy geologiczno-inżynierskiej i instalacji monitoringu in situ. Obejmowały one jedno badanie CID (z jednorodną konsolidacją i drenażem) oraz dziesięć badań CIU (z jednorodną konsolidacją bez drenażu). Procedura badawcza wymagała wykonania testów na co najmniej 2-3 próbkach gruntu, z wstępną konsolidacją i saturacją etapami (z kontrolą parametru ciśnienia porowego B). Ciśnienie konsolidacji zwiększano do wartości 50, 100, 200, 400, 800 kPa w zależ- 
ności od głębokości pobrania próbki. Zwykle konsolidacja trwała, co najmniej 24 godziny aż do momentu, gdy nie obserwowano istotnych zmian objętości próbki. Ścinanie prowadzono z małą prędkością $0,025 \mathrm{~mm} / \mathrm{s}$ w celu uniknięcia generowania dodatkowego ciśnienia porowego. Próbki gruntu o średnicy $50 \mathrm{~mm}$ i wysokości $100 \mathrm{~m}$ były starannie formowane i długotrwale przygotowywane do testów. Pomimo tego wiele próbek węgla brunatnego i gliny uległo uszkodzeniu i rozpadło się podczas ich wycinania. Innego rodzaju trudności były związane $\mathrm{z}$ wydobywaniem próbek NNS z cylindrów Osterberga wykonanych ze stali nierdzewnej. Problemy te wynikały z dużej zwięzłości próbek węgla brunatnego, jego dużego stopnia spękania, zawartości ksylitu oraz wysokiego stopnia przekonsolidowania (OCR). W trakcie wydobywania próbek z cylindrów wzrastała objętość próbek powodując ich dezintegrację na małe części. Na skutek tego, część próbek do badań trójosiowych została wycięta bezpośrednio z rdzenia wiertniczego. Próbki gruntów wycięte $\mathrm{z}$ rdzenia wiertniczego zostały umieszczone $\mathrm{w}$ plastikowych rurach osłonowych szczelnie zamkniętych w celu zabezpieczenia ich przed wysychaniem. Interpretacja wyników testów trójosiowych obejmowała wykresy naprężeń dewiatorowych, całkowitych, wykresy ścieżki naprężeń efektywnych oraz interpretację wielkości kąta tarcia wewnętrznego i spójności na podstawie hipotezy Coulomba-Mohra.

Wyniki. Wyniki badań trójosiowych wraz z wartościami całkowitych i efektywnych parametrów wytrzymałościowych przedstawiono $\mathrm{w}$ tabeli 1 . Najniższe parametry wytrzymałościowe stwierdzono w iłach na głębokości 46,4 $47,4 \mathrm{~m}, \phi=9,8^{\circ}, \mathrm{c}^{\prime}=18,7 \mathrm{kPa}$. Najwyższe w węglu brunatnym na głębokości $33,5-34,0 \mathrm{~m}, \phi=19^{\circ}$, c' $=200 \mathrm{kPa}$ oraz iłach $-33,0-33,5 \mathrm{~m}, \phi=30,3^{\circ}, \mathrm{c}^{\prime}=32 \mathrm{kPa}$. Jednak w niektórych przypadkach możliwe było wykonanie tylko jednego lub dwóch testów z uwagi na brak możliwości pobrania próbek z próbnika Osterberga. Część badań przerwano lub nie wykonano $\mathrm{z}$ powodu uszkodzenia membrany, braku zasilania lub trudności związanych $\mathrm{z}$ wycinaniem próbek do testów.

\section{Monitoring in situ}

System ciagłego monitoringu in situ on-line zainstalowano $\mathrm{w}$ grudniu $2016 \mathrm{r}$. na poziomie $42,6 \mathrm{~m}$ n.p.m. w odkrywce, $210 \mathrm{~m}$, poniżej naturalnego poziomu terenu. Zainstalowano go w otworze wiertniczym o głębokości $100 \mathrm{~m}$, średnicy $132 \mathrm{~mm}$ w rurach osłonowych PCV połączonych $\mathrm{z}$ górotworem masą cementowo-bentonitową. Otwór był

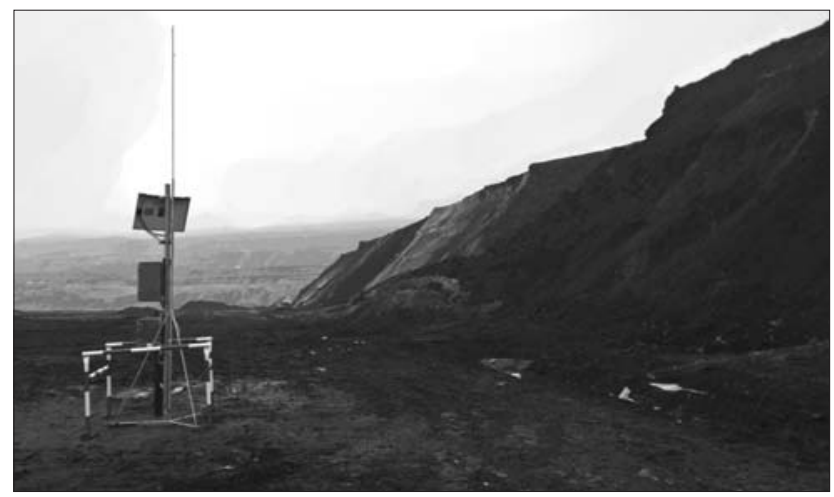

Ryc. 8. Stacja monitoringu on-line w kopalni Betchatów Fig. 8. The on-line monitoring station in Betchatów Mine zlokalizowany w północnej części zachodniego zbocza Pola Bełchatów, w obszarze zagrożenia IV-W w strefie kontaktu NE wysadu solnego (ryc. 8, 10).

Urządzenia monitoringowe składały się z dwustu czujników przemieszczeń 3D rozmieszczonych co $0,5 \mathrm{~m}$. System, o głębokości $100 \mathrm{~m}$, zawierał także trzy magnetometry do kontroli rotacji oraz 50 czujników temperatury gruntu rozmieszczonych co 4 metry. Ciagły system inklinometryczny zbudowany jest ze sztywnych segmentów. Segmenty mogą się przechylać $\mathrm{w}$ dowolnym kierunku, ale nie mogą skręcać. Długość jednego segmentu wynosi 0,5 m. Jeden segment zawiera 3 czujniki pochylenia zakres pomiarowy $\pm 45^{\circ}$, dokładność $0,02 \mathrm{~mm} / \mathrm{m}$, błąd przegubów $+/-0,250$. Każdy oktet (8 segmentów) jest wyposażony w czujnik temperatury gruntu dla korekcji wpływu temperatury na działanie systemu. Maksymalny zasięg urządzeń zależy od szybkości i głębokości ruchów (zwykle nie więcej niż $500 \mathrm{~mm}$ ). System jest wodoodporny do ciśnienia $980 \mathrm{kPa}$. Zasilany jest przez panel słoneczny i akumulator żelowy. Został on dodatkowo wyposażony w czujnik ciśnienia porowego VW umieszczony na głębokości $30 \mathrm{~m}$. Dane GPRS były rejestrowane co 6 godzin i dostępne on-line od 19 grudnia 2016 r. do 9 lutego 2021 r. (wówczas system został zdemontowany, co było związane $\mathrm{z}$ eksploatacją węgla brunatnego w rejonie gdzie się znajdował). Połączenie ze stacja pomiarową było realizowane codziennie w godzinach 11-13. Zarejestrowane dane zostały zinterpretowane i przeanalizowane $\mathrm{w}$ programie komputerowym w postaci wykresów wielkości, skumulowanych, wektorów przemieszczeń oraz wykresów ciśnienia porowego (ryc. 9F). $\mathrm{W}$ celu zapewnienia wczesnego ostrzegania w programie wybrano wartość graniczną $30 \mathrm{~mm}$ na dobę.

Wyniki. Do końca lipca 2019 r. największe przemieszczenia odnotowano na głęb. $35 \mathrm{~m}$, na poziomie $7 \mathrm{~m}$ n.p.m. (ryc. 9A, B). W kierunku nachylenia zbocza (oś x), największe przemieszczenia do $250 \mathrm{~mm}$ zarejestrowano na głęb. 0-45 m. W kierunku prostopadłym (y) przemieszczenia do $50 \mathrm{~mm}$ zarejestrowano do głęb. $70 \mathrm{~m}$. Sumaryczny wypadkowy wektor przemieszczeń wyniósł $290 \mathrm{~mm}$ (ryc. 9C). Największe przemieszczenia wynoszące $80 \mathrm{~mm}$ zaobserwowano w okresie czerwiec-lipiec 2018 r. Wysokie przemieszczenia zaobserwowano również w okresie lutykwiecień 2019 r., kiedy to wzrosły o $70 \mathrm{~mm}$, luty 2017 r. o $60 \mathrm{~mm}$ i sierpień-wrzesień 2017 r. o $35 \mathrm{~mm}$. Ich zwrot był początkowo w kierunku NE, a następnie w przybliżeniu zgodny z inklinacją zbocza ku wschodowi (ryc. 9E). Początkowe ciśnienie porowe wynoszące $258 \mathrm{kPa}$ na głęb. $30 \mathrm{~m}$ zmniejszyło się do $25 \mathrm{kPa}$ po 930 dniach (ryc. 9F). Tak duży spadek ciśnienia porowego był prawdopodobnie spowodowany eksploatacją węgla brunatnego na niższych poziomach kopalni oraz działaniem systemu odwadniania. Kierunek przemieszczeń początkowo był północno-wschodni, a następnie ruchy postępowały zgodnie z nachyleniem zbocza w kierunku wschodnim (ryc. 9D). Aby uniknąć ewentualnych błędów, wyniki z instalacji o głęb. 100 zostały skorygowane o efekty rotacji za pomocą 3 magnetometrów. Rotacja była największa na głębokości $44 \mathrm{~m}$, gdzie dochodziła do 50 stopni (ryc. 9E, G). Przemieszczenia w głębszych warstwach spowodowane były złożonymi czynnikami, w tym zmianami warunków naprężenia w górotworze oraz rozpoczęciem zwałowania nadkładu w wyższych partiach zbocza zachodniego. Na wielkość przemieszczeń ma również wpływ obecność wysadu solnego i naprężenia, jakie mógł on wywierać na sąsiednie war- 


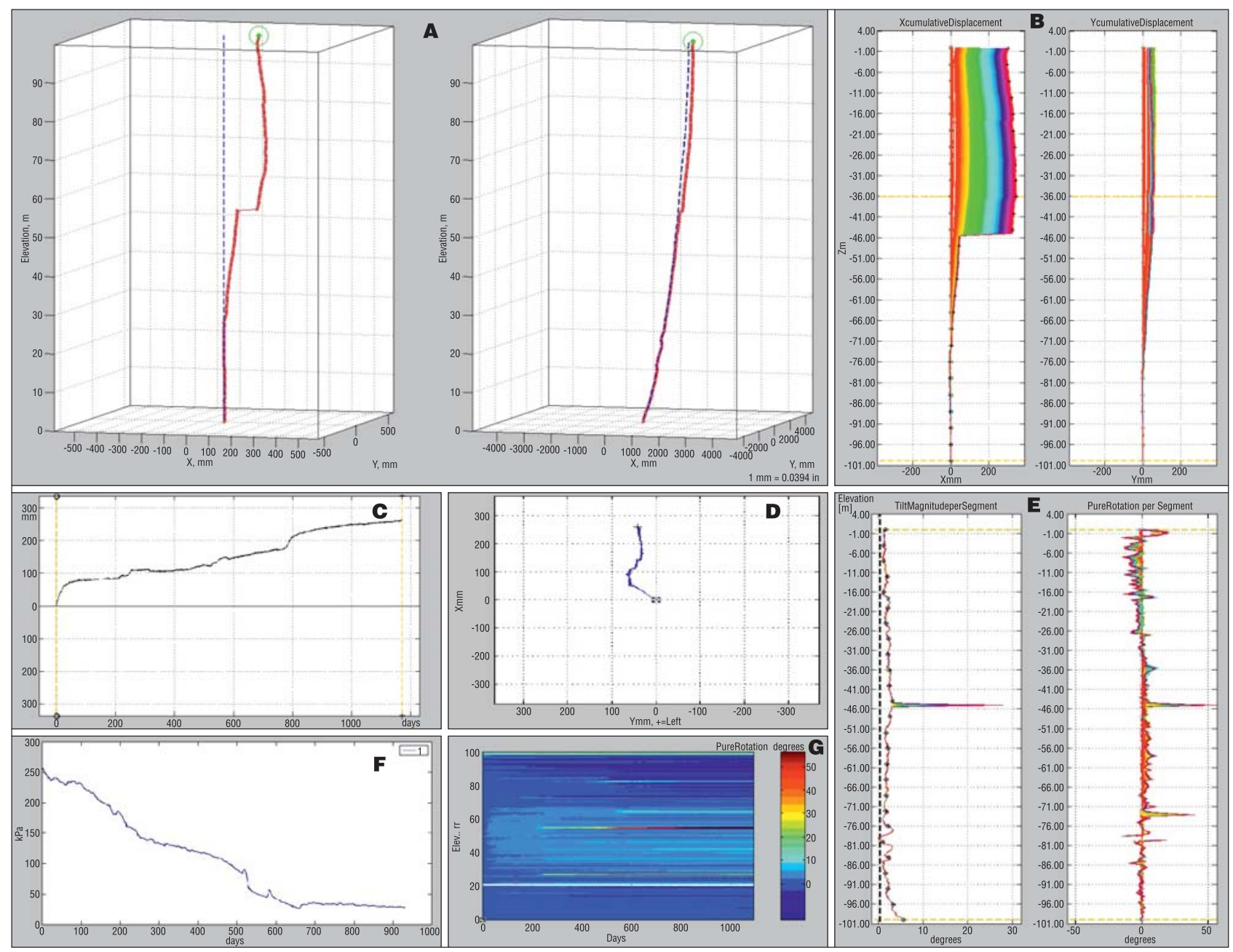

Ryc. 9. Wyniki monitoringu in situ: A - model 3D przemieszczeń [mm, m], B - przemieszczenia skumulowane w kierunku nachylenia stoku - x, i poprzeczne - y [mm], C - przemieszczenia całkowite [mm], D - kierunek i wielkość całkowitych przemieszczeń [mm], $\mathbf{E}$ - rotacja inklinometru - wykres głębokościowy $\left[{ }^{\circ}\right], \mathbf{F}$ - zmiany ciśnienia porowego na głębokości $30 \mathrm{~m}[\mathrm{kPa}], \mathbf{G}$ - rotacja inklinometru wartości kątowe $\mathrm{z}$ trzech magnetometrów $\left[{ }^{\circ}\right]$

Fig. 9. Results of in situ monitoring: $\mathbf{A}$-3D displacement model [mm, m], B - cumulative displacements [mm], $\mathbf{C}$-resultant vector of displacements $[\mathrm{mm}], \mathbf{D}$ - resultant vector of displacements direction $[\mathrm{mm}], \mathbf{E}$ - inclinometer rotation in-deep plot $\left[^{\circ}\right], \mathbf{F}-$ pore pressure at $30 \mathrm{~m}$ depth $[\mathrm{kPa}], \mathrm{G}-$ inclinometer rotation values of rotation angles from three magnetometers $\left[^{\circ}\right]$

stwy. Wszystkie te czynniki zmieniały stan naprężeń w górotworze i sprzyjały uaktywnieniu się głębokich przemieszczeń.

\section{Analizy stateczności}

Metodyka. Analizy stateczności zbocza zachodniego wykonano w dwóch przekrojach poprzecznych (ryc. 1013). Ze względu na złożoną budowę geologiczną wymagały one uogólnienia wprowadzonego modelu geometrycznego zbocza. W tym celu wydzielono dziewięć warstw o zbliżonych parametrach wytrzymałościowych. Interpretację wyznaczonych wartości obliczeniowych wytrzymałości efektywnej wykonano na podstawie zaleceń Eurokodu 7 (PN EN 1997-1:2008, PN-EN 1997-2:2009), w oparciu o tzw. doświadczenie porównawcze. Parametry wytrzymałościowe przyjęte do obliczeń zaczerpnięto z 30 badań podstawowych parametrów fizycznych gruntów i testów trójosiowego ściskania typu CIU oraz oparto na skorygowanych wartościach z wcześniejszych badań i modelowania (Poltegor-Projekt, 2002; Bednarczyk, 2017b) i przedstawiono w tabeli 2. Metoda korekcji efektywnych parametrów obliczeniowych została oszacowana z wyko- rzystaniem wcześniejszych ocen i metod (Phoon, Kulhawy, 1999; Hawrysz, 2013). W przypadku skał mezozoicznych parametry te wyznaczono, wykorzystując klasyfikację GSI (Marinos, Hoek, 2005). Przykładowa geometria wydzielonych warstw została przedstawiona na rycinie 11 .

Analizy stateczności zboczy na zachodnim stoku kopalni wykonano przy użyciu programu do analizy stateczności zboczy FLAC. Wykorzystuje on metodę redukcji wytrzymałości na ścinanie (Shear Strenght Reduction Metod). Pozwala ona na odzwierciedlenie rzeczywistych warunkó naprężeń występujących na zboczach, prowadzących do obniżenia wytrzymałości na ścinanie gruntu aż do etapu utraty jego stateczności. Program umożliwia zdefiniowanie warunków brzegowych przy zastosowaniu różnych modeli gruntów i skał, różnych obciążeń oraz warunków gruntowo-wodnych. Zastosowany model konstytutywny wg hipotezy Coulomba-Mohra wymagał określenia gęstości objętościowej, spójności efektywnej, kąta tarcia wewnętrznego, Liczby Poissona (ew. modułu Younga). Analizę stateczności skarp przeprowadzono w programie FLAC 8.0 2D w dwóch przekrojach 18WE i 20WE w liniach największego spadku zbocza. W obliczeniach zastosowano model konstytutywny gruntu linear-elastic. Uwzględniał on przybliżoną głębokość zalegania poziomu 
zwierciadła wody gruntowej. Wyniki modelowania wskazują na duże zagrożenie osuwiskowe na zboczu zachodnim. Potwierdzają to obserwacje terenowe i monitoring. Należy dodać, że analizy te mają charakter przybliżony, gdyż nie uwzględniają wpływu struktury wysadu solnego Dębiny. Spowodowane to było stosunkowo dużą odległością od wysadu solnego (w skali siatki obliczeniowej dla zbocza) oraz brakiem reprezentatywnych parametrów do obliczeń dla soli znajdującej się w wysadzie.
Metoda SSR okazała się skuteczna w zakresie wykrywania najsłabszych stref analizowanego zbocza. Umożliwiła ona prognozowanie wskaźnika stateczności Fos z większą dokładnością niż metoda równowagi granicznej. Metoda SSR pozwoliła na bardziej wiarygodne oszacowanie rzeczywistej powierzchni poślizgu zbocza, a nie tylko najbardziej prawdopodobnej kołowej powierzchni poślizgu jak ma to miejsce w metodzie LEM. W ten sposób obliczono relacje naprężenie/odkształcenie, prędkość odkształceń $\left[\mathrm{s}^{-1}\right]$, wektory prędkości maksymalnej $[\mathrm{m} / \mathrm{s}]$. Dzięki temu mozna było wstępnie określić powierzchnie poślizgu, strefy występowania największych deformacji oraz prędkość przemieszczeń w obrębie analizowanych zboczy. Oszacowane w programie FLAC współczynniki stateczności Fos nie spełniały wymogów stateczności i wynosiły od 0,85 na odcinku $18 \mathrm{WE}$ (w pobliżu osuwiska) do 1,14 na odcinku $20 \mathrm{WE}$ (ryc. 12). W złożonych warunkach geologiczno-inżynierskich wiarygodność modelowania numerycznego może zależeć od wielu czynników związanych z niepewnością parametrów obliczeniowych, uproszczonym modelem geometrycznym, wprowadzonymi parametrami wytrzymałościowymi, długością analizowanych przekrojów oraz zastosowaną siatką obliczeniową. Analizy stateczności wykonano również z wykorzystaniem równowagi granicznej LEM, na podstawie metod Bishopa i Janbu (ryc. 13). Rezultaty wszystkich analiz przedstawiono w tabeli 3. Wyniki analizy lokalnej i wizji terenowej wskazują na duże zagrożenie osuwiskowe na zachodnim zboczu kopalni. Na powstanie osuwisk złożyło się wiele czynników, takich jak wpływy eksploatacji górniczej, parametry geometryczne i wytrzymałościowe zbocza oraz wpływ wysadu solnego. Wpływ struktury solnej nie został uwzględniony w tych wstępnych analizach lokalnych ze względu na stosunkowo dużą odległość od wysadu solnego (od środka wysadu do górnej granicy zbocza

Fig. 10. Location of slope stability analyses, risk zones, and monitoring instrumentation

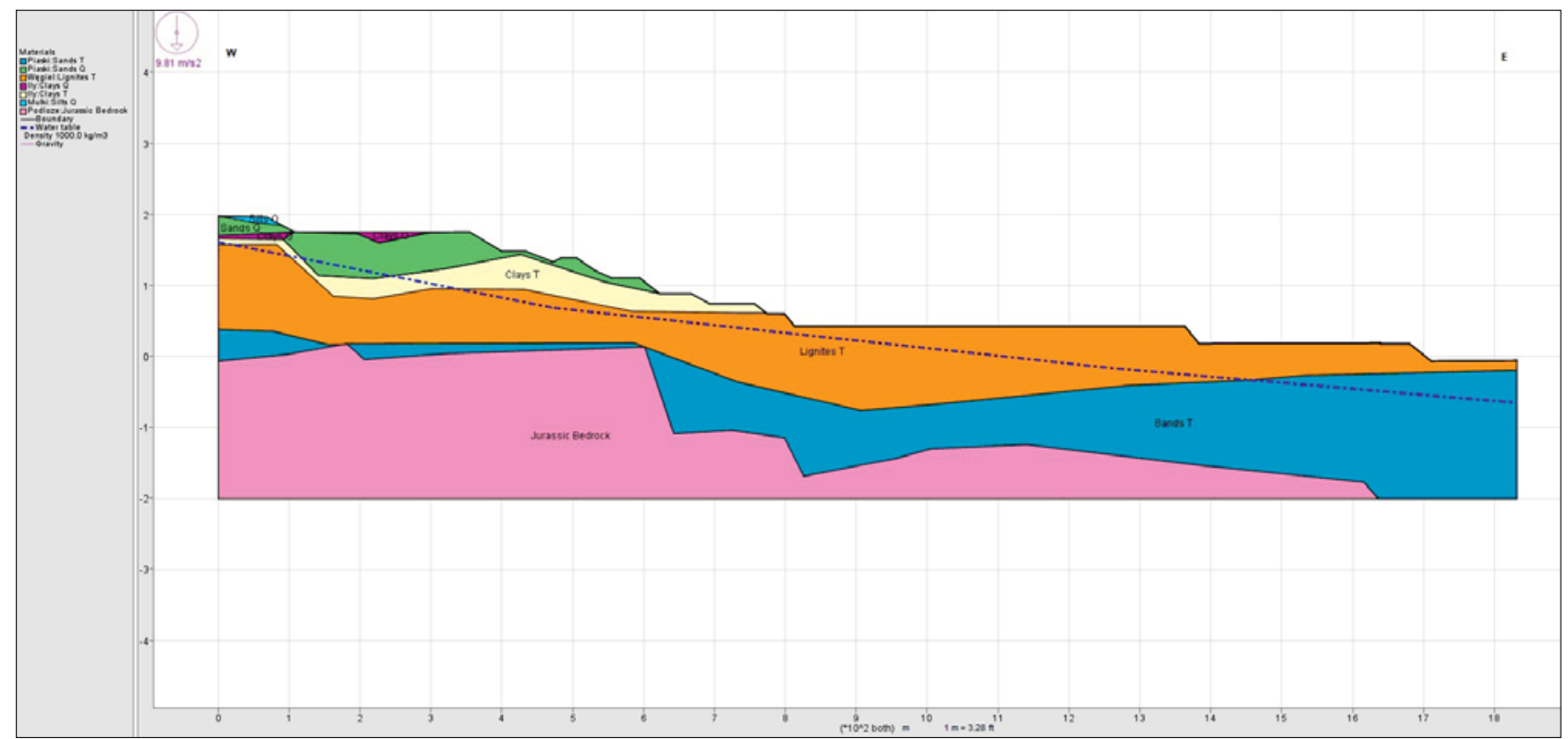

Ryc. 11. Analiza stateczności skarpy 20WE, metoda SSR, warstwy geologiczno-inżynierskie

Fig. 11. Slope stability analysis 20WE, SSR Method, geological-engineering layers 
Tab. 2. Parametry wytrzymałościowe zaimplementowane w analizie numerycznej

Table 2. Strength parameters implemented in the numerical analysis

\begin{tabular}{|l|l|c|c|c|}
\hline $\begin{array}{c}\text { Nr } \\
\text { No. }\end{array}$ & \multicolumn{1}{|c|}{$\begin{array}{c}\text { Typ gruntów / skal } \\
\text { Soil / rock type }\end{array}$} & {$\left[\mathbf{k N} / \mathbf{m}^{3}\right]$} & $\mathbf{c}[\mathbf{k P a}]$ & {$\left[{ }^{\top}\right]$} \\
\hline 1 & $\begin{array}{l}\text { piasek (Q) } \\
\text { sand }\end{array}$ & 18,5 & 1,0 & 30,0 \\
\hline 2 & $\begin{array}{l}\text { glina zwałowa (Q) } \\
\text { till }\end{array}$ & 21,8 & 40,0 & 9,2 \\
\hline 3 & $\begin{array}{l}\text { mukek (Q) } \\
\text { mud }\end{array}$ & 21,3 & 40,0 & 15,0 \\
\hline 4 & $\begin{array}{l}\text { ił (Q) } \\
\text { clay }\end{array}$ & 20,8 & 80,0 & 5,3 \\
\hline 5 & $\begin{array}{l}\text { ił (N) } \\
\text { clay }\end{array}$ & 21,1 & 89,0 & 5,8 \\
\hline 6 & $\begin{array}{l}\text { wegiel brunatny (N) } \\
\text { lignite albo brown coal }\end{array}$ & 11,8 & 170,0 & 14,8 \\
\hline 7 & $\begin{array}{l}\text { piasek (N) } \\
\text { sand }\end{array}$ & 19,5 & 1,0 & 32,0 \\
\hline 8 & $\begin{array}{l}\text { podłoże mezozoiczne } \\
\text { wapienie, margle (M) } \\
\text { Mesozoic bedrock, } \\
\text { limestones, marls }\end{array}$ & 25,0 & 338,0 & 27,1 \\
\hline
\end{tabular}

Tab. 3. Wyniki analiz stateczności na zachodnim zboczu Pola Bełchatów

Table 3. Results of slope stability analysis at the western slope of Bełchatów Mine of the Bełchatów Field

\begin{tabular}{|l|c|c|}
\hline $\begin{array}{c}\text { Metoda } \\
\text { Method }\end{array}$ & $\begin{array}{c}\text { Fos } \\
\mathbf{2 0 ~ W E}\end{array}$ & $\begin{array}{c}\text { Fos } \\
\mathbf{1 8 ~ W E}\end{array}$ \\
\hline SSR Flac & 0,83 & 1,14 \\
\hline LEM Bishop & 1,34 & 1,16 \\
\hline LEM Janbu & 1,46 & 1,27 \\
\hline
\end{tabular}

zachodniego ok. $500 \mathrm{~m}$ ) i brak reprezentatywnych danych, ale niewątpliwie należy go wprowadzić do przyszłych analiz. Powinno to uwzględniać właściwości reologiczne soli w wysadzie solnym i otaczających ją warstwach. W tak złożonych warunkach geologiczno-inżynierskich wiarygodność analiz stateczności zależy od kilku czynników. Błędy interpretacyjne mogą mieć różne podłoże. Najczęściej są one związane są z niepewnością parametrów obliczeniowych oraz uproszczonym modelem geometrycznym. Mogą także wynikać z niewłaściwej aproksymacji modeli geometrycznych, stosowania uproszczonych parametrów wytrzymałościowych, dużej długości analizowanych przekrojów oraz zastosowanej nieodpowiedniej siatki obliczeniowej.

Zbocze zachodnie i jego najbliższe otoczenie są podporządkowane bardzo złożonemu stanowi naprężeń. Znaczne zmiany naprężeń na zboczach spowodowane eksploatacją węgla brunatnego i oddziaływaniem kopuły solnej mogą być przyczyną procesów osuwiskowych, polegających na znacznych deformacjach, relaksacji naprężeń, otwieraniu się naturalnych spękań, infiltracji i zmianie warunków przepływu wód gruntowych. Duże zmiany naprężeń na skutek bardzo głębokiej eksploatacji mogą powodować reaktywację uskoków, powierzchni tektonicznych i spękań oraz wywoływać przemieszczenia wgłębne. W analizie nie uwzględniono obniżonych parametrów geotechnicznych na powierzchniach sprzyjających aktywacji osuwisk, np. na preferowanych granicach warstw, granicy czwartorzęd / neogen, paleoosuwiskach itp. Wprowadzenie tych powierzchni i związane z tym obniżone wartości parametrów wytrzymałościowych mogą również niekorzystnie wpływać na wartość Fos.

\section{PODSUMOWANIE}

Prace prezentowane $\mathrm{w}$ artykule doprowadziły do wdrożenia w KWB Bełchatów nowych metod monitoringu. Uczestniczyło w nich kilka europejskich ośrodków badawczych i naukowych. Wyniki badań dostarczyły nowych danych dotyczące osuwisk, ciśnienia porowego i stateczności zboczy do kontroli przemieszczeń w trakcie eksploatacji. Przemieszczenia powierzchni terenu wokół kopalni były badane przy użyciu pomiarów PSI na dużym obszarze. Analizy te wykazały, że metoda PSI ma ograniczenia dla dużych prędkości przemieszczeń oraz w przypadku głęboko położonych, słabo widocznych obszarów, w których przemieszczenia zachodzą zgodnie z kierunkiem ruchu dla satelitów. Pomiary dla poszczególnych zboczy pozyskano także za pomocą skanowania LiDAR UAV oraz TLS. Pomiary inklinometryczne in situ wykryły przemieszczenia o wielkości $290 \mathrm{~mm}$ do głęb. $46 \mathrm{~m}$ (poziom od 40 do $-6 \mathrm{~m}$ n.p.m.) w czasie ponad 2,5 roku (930 dni). $\mathrm{Na}$ podstawie pomiarów PSI określono przemieszczenia 781206 punktów w siatce $30 \times 30 \mathrm{~km}$. W ciągu dwóch lat pomiarów zidentyfikowano 14 stref przemieszczeń. Występowały one na południowym zboczu Pola Bełchatów, w obrębie zewnętrznego zwałowiska nadkładu Pola Szczerców oraz w kilku innych rejonach. Największe osiadania, dochodzące do $60 \mathrm{~mm} / \mathrm{rok}$, stwierdzono na wschodnim zboczu zewnętrznego zwałowiska nadkładu Pola Szczerców. W rejonie zbocza zachodniego Pola Bełchatów, w którym zainstalowano monitoring wgłębny, w pomiarach PSI stwierdzono znacząco mniejsze przemieszczenia niż wykryte poprzez monitoring wgłębny. W celu bardziej dokładnego scharakteryzowania przemieszczeń powierzchniowych zbocza zachodniego metodą satelitarną PSI konieczne jest zastosowanie specjalnych reflektorów. Skanowanie LiDAR UAV oszacowało przemieszczenia powierzchni na zachodnim stoku na $7 \mathrm{~mm}$ w ciągu 3 miesięcy. Porównanie wyników z różnych metod monitoringu potwierdziło różnice pomiędzy przemieszczeniami powierzchniowymi, które dobrze charakteryzują duże obszary, a przemieszczeniami wgłębnymi gruntów in situ. Należy podkreślić, że przemieszczenia powierzchniowe i wgłębne, szczególnie dotyczące głębokich osuwisk mogą wykazywać inne wyniki. Do prognozowania zachowania stref osuwiskowych najbardziej dokładne są pomiary wgłębne in situ. Metody inklinometryczne mogą wykryć małe przemieszczenia gruntu wcześniej i dokładniej. Te małe przemieszczenia zazwyczaj poprzedzają duże osuwiska na najbardziej zagrożonych obszarach. Konwencjonalne inklinometry zwykle mierzą przemieszczenia gruntu do 110 mm i mogą nie być właściwe przy większych zakresach. Należy również zaznaczyć, że nie każdy skaner laserowy sprawdzi się w przypadku zboczy skanowanych z odległości ok. $3 \mathrm{~km}$, co było wymagane w przypadku kopalni Betchatów. System monitoringu on-line wyposażony w magnetometry pozwolił mierzyć znacznie większe wielkości przemieszczeń, które do lutego 2021 r. osiągnęły $300 \mathrm{~mm}$. Stosowane metody powinny być zawsze dopasowane do rodzaju i wielkości przemieszczeń. Na obszarach o dużych przemieszczeniach, liczonych w metrach, instala- 


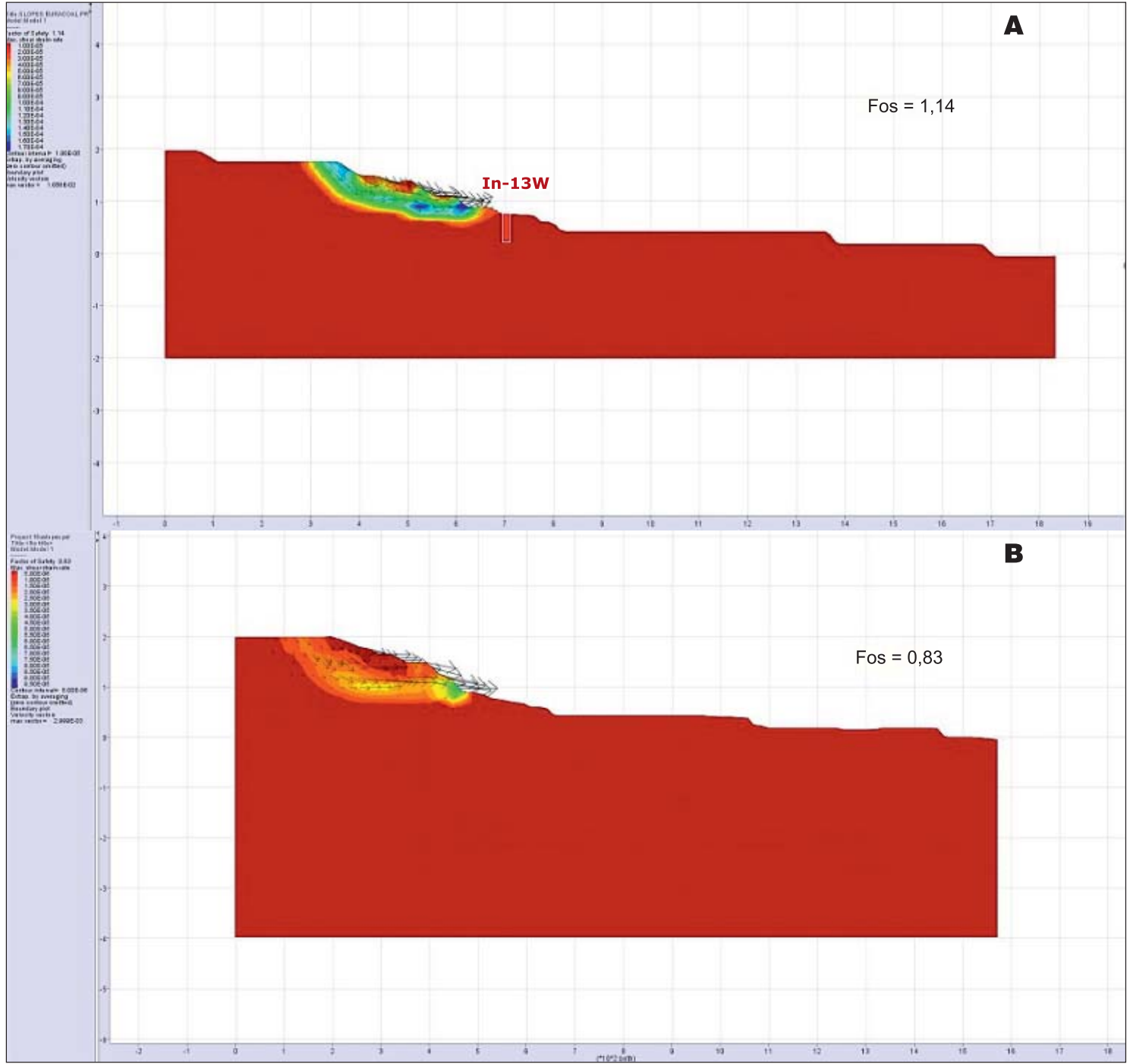

Ryc. 12. Analiza stateczności skarpy, metoda SSR 20WE Fos $=1,14$ (A), 18 WE Fos $=0,83$ (B)

Fig. 12. Slope stability analysis, SSR method, 20WE Fos $=1.14$ (A), 18 WE Fos $=0.83$ (B)

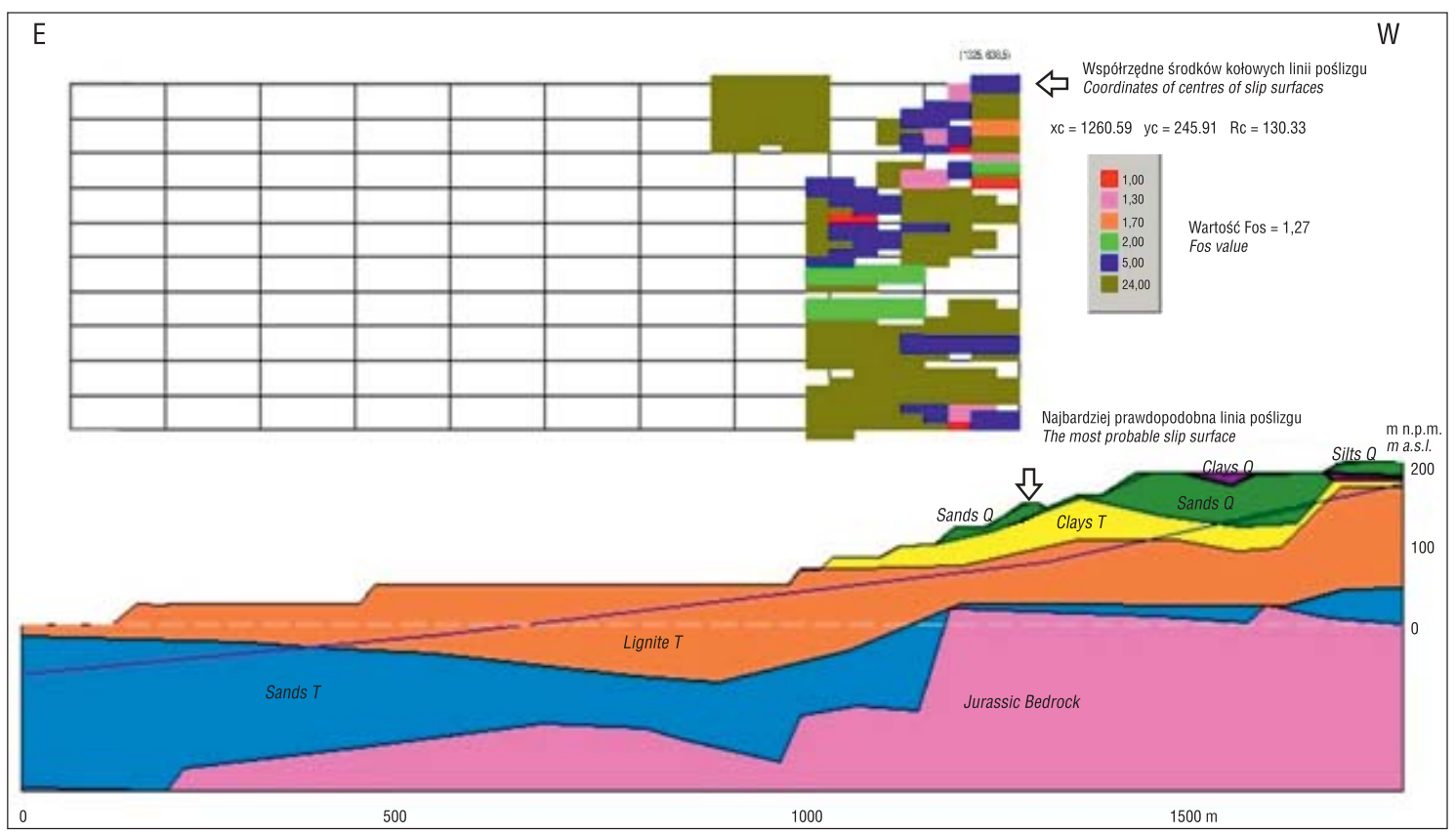

Ryc. 13. Analiza stateczności skarpy, 20WE, metoda LEM Janbu, Fos $=1,27$

Fig. 13. Slope stability analysis, 20WE, LEM Janbu Method, Fos $=1.27$ 
cja oprzyrządowania in situ może być bezużyteczna i nieefektywna. Lepsze możliwości mogą w takim przypadku dawać systemy skaningu lotniczego. Pozwalają one na stosunkowo szybkie pozyskiwanie różnorodnych danych monitoringowych nawet w warunkach dużych przemieszczeń. Dodatkowo mogą być wykorzystane do określenia warstw w obrębie zboczy, lokalizacji struktur geologicznych, uskoków i nieciąłłości. Dane lotnicze, satelitarne i TLS powinny być zawsze starannie kalibrowane poprzez standardowe geodezyjne punkty odniesienia, ujednolicone w czasie i w miarę możliwości skalowane inklinometrycznymi pomiarami wgłębnymi. Dokładne porównanie wyników przemieszczeń powierzchniowych wykonanych na podstawie pomiarów satelitarnych PSI, lotniczych LiDAR UAV, za pomocą naziemnego skanowania laserowego oraz monitoringu in situ było utrudnione z powodu różnych okresów wykonywanych pomiarów oraz uwarunkowaniami poszczególnych metod pomiarowych. Dla zbocza zachodniego, gdzie wykonywano pomiary przemieszczń wgłębnych in situ i przemieszczeń powierzchniowych, wykazały one znaczące różnice. Przemieszczenia określone za pomocą PSI wyniosły $10 \mathrm{~mm}$, LiDAR UAV - $24 \mathrm{~mm}$ (przy dokładności pomiarów ok. 2-3 mm). Przemieszczenia wgłębne in situ w tym samym okresie wyniosły $100 \mathrm{~mm}$ do głęb. $46 \mathrm{~m}$ (przy dokładności pomiaru rzędu 0,1-0,3 mm). Należy zaznaczyć, że przemieszczenia powierzchniowe i wgłębne, chociaż są ze sobą związane, mają inne wartości. Za pomocą pomiarów przemieszczeń powierzchniowych zazwyczaj nie można określić całkowitej wielkości przemieszczeń wgłębnych. Wszystkie te metody mają duży potencjał, jednak powinny być starannie skalibrowane. Za pomocą monitoringu in situ sprawdzono stateczność zbocza zachodniego. Charakteryzowało się one niskim wskaźnikiem stateczności Fos $=0,83-1,10$. W pozostałych rejonach kopalni badania satelitarne PSI pozwoliły na wydzielenie 14 stref osuwiskowych na obszarze całego zakładu górniczego i obszarach przyległych.

Wykonane badania mają swoje ograniczenia związane z zakresem badań, przyjętymi okresami badań, różnymi rodzajami przemieszczeń będących przedmiotem pomiarów, zespołami badawczymi oraz zastosowaną aparatura badawczą. Część z wykonanych prac miała charakter testowy i powinna być kontynuowana. Przemieszczenia powierzchniowe interpretowane na podstawie pomiarów PSI różniły się od tych interpretowanych na podstawie pomiarów in situ, ponieważ mają one ograniczenia związane ze zmniejszoną widocznością położonych głęboko w odkrywce punktów i kierunkiem ruchu satelity. Ograniczenia dla PSI były szczególnie widoczne na obszarach osuwiskowych, gdzie wielkość przemieszczeń była bardzo duża, oraz na zwałowiskach, gdzie morfologia zmieniała się bardzo szybko. Poza tymi ograniczeniami, pomiary PSI były bardzo korzystne dla wczesnego wykrywania inicjacji osuwisk na dużych obszarach. Całkowite wyeliminowanie zagrożeń osuwiskowych w kopalniach odkrywkowych węgla brunatnego nie jest możliwe. Znajomość procesów zachodzących w przeszłości, doświadczenia z wdrażania nowych metod badawczych i duża ilość nowych danych pomiarowych pozyskanych $\mathrm{w}$ ramach projektu Slopes powinny się przyczynić do lepszej identyfikacji zagrożeń i doboru optymalnych środków przeciwdziałania. $\mathrm{Na}$ obszarach szczególnie narażonych na osuwiska przydatne może być opracowanie indywidualnych metod zdalnego monitoringu oraz szczegółowych procedur interpretacji wielkości, głębokości i kierunków przemieszczeń. Należy też podkreślić, że prognozowanie występowania osuwisk w polskich kopalniach odkrywkowych węgla brunatnego jest zazwyczaj bardzo złożone. Wdrożenie przedstawionych metod powinno mieć korzystny wpływ na lepsze poznanie zagrożeń i zwiększenie możliwości wczesnego przeciwdziałania.

Projekt UE SLOPES RFCS-CT-2015-00001 Smarter Lignite Open Pit Engineering Solutions (Inteligentne Rozwiązania Inżynierskie dla Kopalni Węgla Brunatnego) był finansowany przez Europejski Fundusz Badawczy Węgla i Stali oraz Ministerstwo Nauki i Szkolnictwa Wyższego, bez których nie byłaby możliwa jego realizacja. Chciałbym także podziękować firmie PGE GIEKSA Oddział w Bełchatowie za udostępnienie terenu badań i pomoc w realizacji projektu oraz partnerom projektu Slopes, a w szczególności jego koordynatorowi - prof. Alec Marshall z Centrum Geomechaniki Uniwersytetu Nottingham (UK), uczestnikom projektu z Camborne School of Mines Uniwersytetu Exeter (UK), Instytutu INERIS (Francja), Instytutu CERT (Grecja), Instytutu VUHU (Czechy), firmom geotechnicznym GECONTROL i SUBTERRA (Hiszpania) oraz firmie GAP (spółka Politechniki Bari - Włochy) za pomoc w realizacji projektu. W tym miejscu pragnę też podziękować Redakcji Przeglądu Geologicznego za umożliwienie publikacji artykułu i za uwagi Recenzentów.

\section{LITERATURA}

ANG A.H-S., TANG W.H. 2007 - Probability Concepts in Engineering: Emphasis on Applications to Civil and Environmental Engineering, 2e Instructor Site: Emphasis on Applications to Civil and Environmental Engineering second editon, Wiley \& Son, 199-244.

BAECHER G.B., CHRISTIAN J.T. 2003 - Reliability and Statistics in Geotechnical Engineering. Wiley \& Sons, 11-14.

BEDNARCZYK Z. 2017a - Slope Stability Analysis for the Design of a New Lignite Open-Pit Mine. Proc. Eng., https://doi.org/10.1016/j.proeng.2017.05.153

BEDNARCZYK Z. 2017b - Landslide Monitoring and Counteraction Technologies in Polish Lignite Opencast Mines, Advancing Culture of Living with Landslides, Vol 5, Landslides in Different Environments edited by Matjaz Mikoz, Vít Vilímek, Yueping Yin, Kyoji Sassa, Springer International; doi 10.1007/978-3-319-5348

BEDNARCZYK Z. 2018 - Identification of flysch landslide triggers using nearly real-time monitoring data-an example from the Carpathian Mts., Poland. Eng., Geol., 244: 41-56.

BEDNARCZYK J., NOWAK A. 2010 - Strategie i scenariusze rozwoju produkcji energii elektrycznej z węgla brunatnego w obecnych warunkach. Górn. Geoinż., 34 (4): 67-83.

BEDNARCZYK Z., SANDVEN R. 2004 - Comparison of CPTU and laboratory tests interpretation of Polish and Norwegian clays. [W:] Fonseca V. (red.), International Geotechnical and Geophysical Site Characterization Conference ISC-2 Porto, Millpress, 1791-1799.

CEN (1994). EUROCODE 7, Geotechnical design. Part 1:Gen. rules, ENV1997-1E. Brussels.

CHRISTIAN J.T., LADD C.C. 1994 - Reliability applied to slope stability analysis. J. Geot. Engin., 120 (12): 2180-2207.

CIUK E., PIWOCKI M. 1980 - Geologia trzeciorzędu Rowu Kleszczowa i jego otoczenia. Przew. LII Zjazdu PTG: 38-56.

COOPER M.A. 1987 - Control Surveys in Civil Engin. William Collins Sons \& Co., London.

CRUDEN D.M., VARNES D.J. 1996 - Landslide types and processes. [W:] Turner A.K., Schuster G.P. (red.), Landslides, investigation and mitigation, Vol. 3. Special report 247, Transportation Res. Board, Nat. Res. Council National Acad. Press, Washington: 36-75.

CZARNECKI L., ORGANISCIAK B. 2015 - Zagrożenie utraty stateczności zbocza południowego zbudowanego ze skał mezozoicznych w obszarze rowu drugiego rzędu. III Kongres Górniczy C-5.

CZARNECKI L., FELISIAK I. 2004 - Paleo-landslide block of the Southern Frame Fault and its influence on mining operations in the Second-order Graben at the Belchatow Lignite Mine. Warsztaty Górnicze Conf. Proc., 125-138.

DANE EUROSTATU 2018 - Wydobycie węgla w UE. | Selected News https://selectednews.info/pl/wydobycie-wegla-w-ue-dane-eurostatu/; dostęp 18.08.2021 r. 
DEMIREL N., EMIL M.K., DUZGUN H.S. 2011 - Surface coal mine area monitoring using multi-temporal high-resolution satellite imagery. Inter. J. Coal Geol., 86: 3-11.

DMITRUK S. 1984 - Problems of geotechnical modeling in open-cast mining. Wyd. Geol.

FLISIAK J., RYBICKI S., TYLIKOWSKI M. 2014 - Landslide risk assessment in Belachatow and Turow opencast mines. Prz. Geol., 10/2: 563-572.

HAWRYSZ M. 2013 - Metody szacowania efektywnych parametrów wytrzymałościowych. Geoinż. Drogi Mosty Tunele, 3: 34-44.

JANECKI W., BEDNARCZYK Z., ZEMBRONSKI J. 1999 - Rozpoznanie warunków geotechnicznych na zboczu południowym KWB Bełchatow w rejonie zejścia do rowu drugiego rzędu na poziomie +124/+94 m n.p.m. w czwartym piętrze górniczym pomiędzy liniami przekrojów 60 i $61 \mathrm{SN}$. Geosoft Wrocław.

JOŃCZYK W., ORGANIŚCIAK B. 2010 - Zagrożenia naturalne w KWB Bełchatów rozpoznanie i przeciwdziałanie. Górn. Geoinż., 34 (4): 249-257.

KASZTELEWICZ Z. 2012 - Węgiel brunatny w Polsce i na świecie. Węgiel Brunatny, 78 (1): 7-13.

KOSSOWSKI L., OLSZEWSKI B., SOWINSKI L., WOJTURSKA M., SOWA J. 1992 - Reinterpretacja budowy geologicznej KWB Bełchatów pomiędzy liniami 42-70NS. Arch. KWB Bełchatów.

KULHAWY F.H. 1992 - On the evaluation of static soil properties. In: Geotechnical Special Publication 31: Stability and performance of slopes and embankments II, ASCE. Berkeley, California: 95-115.

LU D., WENG Q. 2007 - A survey of image classification methods and techniques for improving classification performance. Intern. J. Remote Sensing, 28: 823-870.

MARINOS VP., HOEK E. 2005 - The Geological Strength Index: Applications and limitations. Bull. Eng. Geol. Environ., 64: 55-65.

MARSHALL A., REZANIA M., HERON C., MARSH S., SMITH M. ZANGANEH H., MASOUDIAN M., HASHEMI A., BOWMAN A. FERNÁNDEZ A., GULLÓN A., RODRIGO C., DE CABO M., POZO V., DE PAZ D., GALERA J., BEDNARCZYK Z., SVOBODA P., BURDA J, KOUKOUZAS N., DELIVERIS A., ZEVGOLIS I., COGGAN J., EYRE M., VANNESCHI M., COCCIA S., CAUVIN L., AL HEIB M., RICHARD T.
- 2019 Draft Final Slopes Project Report Deliverable 4.3.1. European Commission Research Programme of the Research Fund for Coal and Steel, Technical Group: TGC1, Grant Agreement number RFCR-CT-201500001 Project Slopes - Smarter Lignite Open Pit Engi-neering Solutions: $1-120$.

NGUYEN V.U., CHOWDHURY R.N. 1984 - The probabilistic study of spoil pile stability in strip coal mines - two techniques compared. Int. J. Rock Mech. Min. Sci. Geom., A.21: 303-312.

PATRZYK J. 1996 - Zagrożenie osuwiskowe w KWB Bełchatów. Mies. WUG, 2/96: 13-16.

PHOON K., KULHAWY F.H. 1999 - Characterization of geotechnical variability, Canadian. Geotech. J., 36: 612-624.

PN EN 1997-1:2008 - Eurocode 7, Projektowanie Geotechniczne. Cz. 1: Zasady ogólne.

PN-EN 1997-2:2009 - Eurocode 7, Projektowanie Geotechniczne. Cz 2: Badania polowe.

POLTEGOR-PROJEKT 2002 - Aktualizacja projektu dla Pola Szczerców. Wydobycie maksymalne wraz z biznesplanem, Wrocław. Nr projektu -1030.1325 .002 .

RYBICKI S. 1996 - Osuwiska w Polskich kopalniach odkrywkowych węgla brunatnego). Wyd. PKrak., 57-164.

SCHROETER L., GLÄBER C. 2011 - Analyses and monitoring of lignite mining lakes in East Germany with spectral signatures of Landsat TM. Int. J. Coal Geol., 86: 27-39.

WELSCH W. HEUNECKE O., KUHLMANN H. 2000 - Auswertung geodätischer Überwachungsmessun-gen [W:] Möser et al. (red.), Wichmann Verlag, Heidelberg. Wilkins.

WHITMAN R.V. 1984 - Evaluating calculated risk in geotechnical engineering. J. Geot. Engin., 110 (2): 143-188.

WILKINS R., BASTIN G., CHRZANOWSKI A. 2003 - ALERT: a fully automated real-time monitoring system. [W:] Proc. of the $11^{\text {th }}$ FIG Symposium on Deformation Measurements, Santorini, Greece: 209-216.

WU T.H.H. 2008 - Reliability analysis of slopes. [W:] Reliability-bas. Design in Geotechnics.

Praca wpłynęła do redakcji 31.05.2021 r.

Akceptowano do druku 23.08.2021 r. 